\title{
Consensus Report on Patient Blood Management in Cardiac Surgery by Turkish Society of Cardiovascular Surgery (TSCVS), Turkish Society of Cardiology (TSC), and Society of Cardio-Vascular-Thoracic Anaesthesia and Intensive Care (SCTAIC)
}

\author{
Kalp Cerrahisinde Hasta Kan Yönetimine ilişkin Uzlaşı Raporu \\ Türk Kalp Damar Cerrahisi Derneği (TKDCD), Türk Kardiyoloji Derneği (TKD) ve \\ Göğüs-Kalp-Damar Anestezi ve Yoğun Bakım Derneği (GKDAYB)
}

\author{
Serkan Ertugay' (D), Türkan Kudsioğlu² (D), Taner Şen³ (D, Patient Blood Management Study Group Members \\ 'Department of Cardiovascular Surgery, Ege University School of Medicine, Izmir, Turkey \\ ${ }^{2}$ Anesthesiology and Reanimation, University of Health Sciences, Siyami Ersek Thoracic and Cardiovascular Surgery Center, Istanbul, Turkey \\ ${ }^{3}$ Department of Cardiology, University of Health Sciences, Kütahya
}

\begin{abstract}
Anemia, transfusion and bleeding independently increase the risk of complications and mortality in cardiac surgery. The main goals of patient blood management are to treat anemia, prevent bleeding, and optimize the use of blood products during the perioperative period. The benefit of this program has been confirmed in many studies and its utilization is strongly recommended by professional organizations. This consensus report has been prepared by the authors who are the task members appointed by the Turkish Society of Cardiovascular Surgery, Turkish Society of Cardiology (TSC), and Society of Cardio-Vascular-Thoracic Anaesthesia and Intensive Care to raise the awareness of patient blood management. This report aims to summarize recommendations for all perioperative bloodconserving strategies in cardiac surgery.
\end{abstract}

Keywords: Cardiac surgery, patient blood management, transfusion, bleeding.

Cardiac surgery constitutes a high risk for bleeding and transfusion due to multiple causes such as procedures, patient characteristics, medications, and cardiopulmonary bypass (CPB). Anemia, transfusion, and bleeding independently increase the risk for complications and mortality ${ }^{[1]}$ The term patient blood management (PBM) includes strategies to increase patient's red cell mass,
$\ddot{O} Z$

Anemi, transfüzyon ve kanama kalp cerrahisinde bağımsız olarak komplikasyon ve mortalite riskini artırır. Hasta kan yönetiminin başlica amacı perioperatif dönemde aneminin tedavisi, kanamanın önlenmesi ve kan ürünü kullanımının optimize edilmesidir. Bu programın yararı birçok çalışmada kanıtlanmış olup, kullanımı birçok mesleki dernek tarafından önemle önerilmektedir. Bu uzlaşı raporu, Türk Kalp Damar Cerrahisi Derneği (TKDCD), Türk Kardiyoloji Derneği (TKD) ve Göğüs-Kalp-Damar Anestezi ve Yoğun Bakım Derneği'nin çalışma grubu üyeleri tarafından hasta kan yönetimine ilişkin farkındalığ 1 artırmak amacıyla hazırlanmıştır. $\mathrm{Bu}$ raporda, kalp cerrahisinde perioperatif dönemde kan koruyucu stratejilerin tümüne ilişkin öneriler özetlenmiştir.

Anahtar sözcükler: Kalp cerrahisi, hasta kan yönetimi, transfüzyon, kanama.

to prevent bleeding, and to optimize the use of blood products. Its main benefit has been confirmed by many studies and its utilization is strongly recommended by professional organizations..$^{[2]}$ The success is only achieved, if it is applied in a multidisciplinary manner by a team including a surgeon, cardiologist, anesthesiologist, perfusionist, and nurse.

Received: October 03, 2019 Accepted: October 10, 2019 Published online: October 23, 2019

Correspondence: Serkan Ertugay, MD. Ege Üniversitesi Tip Fakültesi Kalp ve Damar Cerrahisi Anabilim Dalı, 35100 Bornova, Izmir, Turkey Tel: +90533-5262950 e-mail: serkanertugay80@gmail.com

Cite this article as:

Ertugay S, Kudsioğlu T, Şen T, Patient Blood Management Study Group Members. Consensus Report on Patient Blood Management in Cardiac Surgery by Turkish Society of Cardiovascular Surgery (TSCVS), Turkish Society of Cardiology (TSC), and Society of Cardio-Vascular-Thoracic Anaesthesia and Intensive Care (SCTAIC). Turk Gogus Kalp Dama 2019:27(4):429-450 


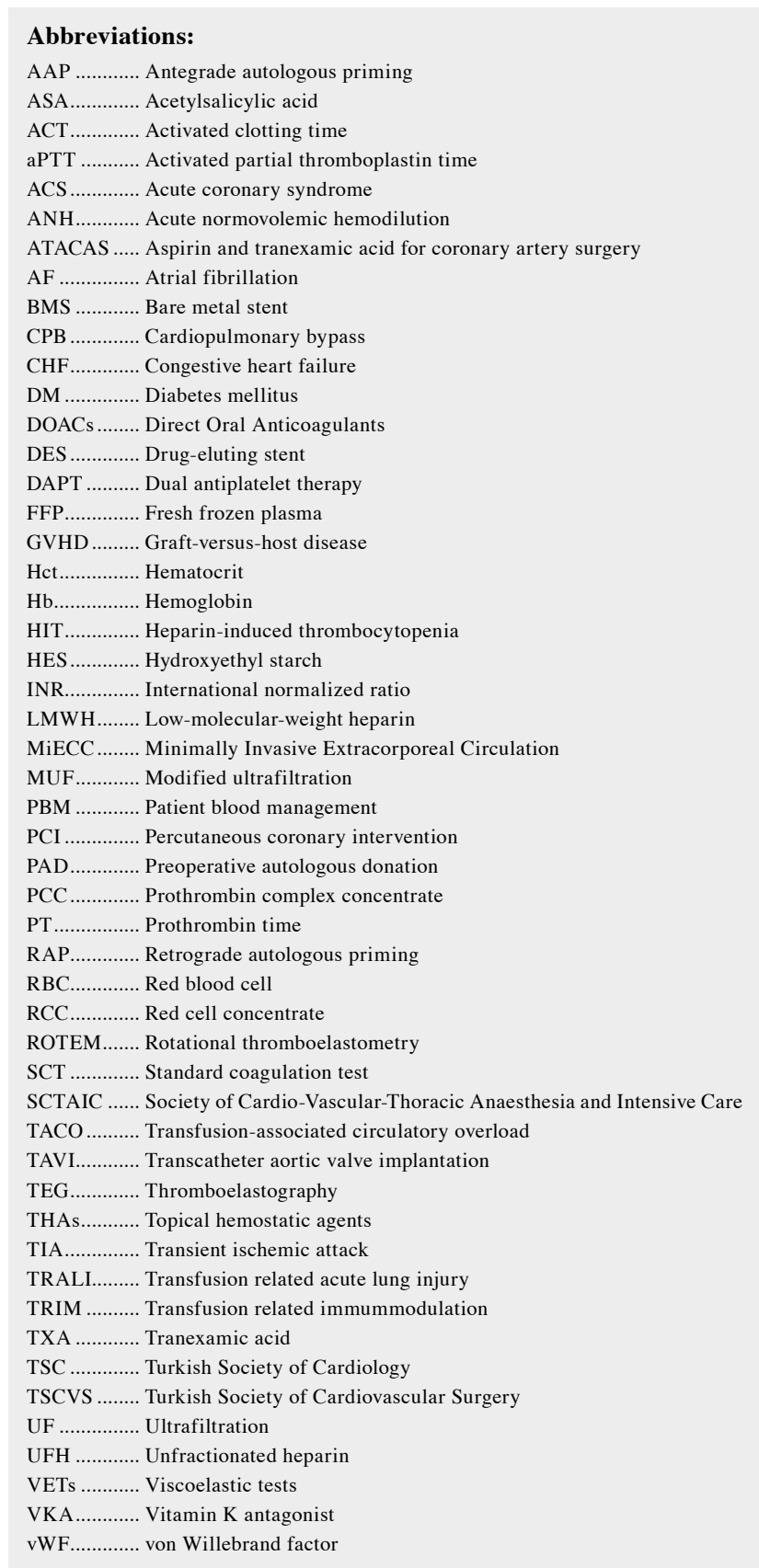

Blood management during cardiac surgery starts with risk identification of bleeding and thrombosis, treatment of anemia, and optimizing antithrombotic treatments. Preoperative consultation of the patient for PBM in clinics may provide excellent care in these patient populations. Subsequently, intraoperative bloodconserving strategies including a meticulous surgical technique, optimal management of anticoagulation, and appropriate use of hemostatic agents would serve to protect patient's blood. Finally, the optimal treatment of coagulopathy and bleeding with an appropriate use of blood products would definitely decrease the risk for complications.

This consensus report is an extended summary of the book prepared by the authors who are the task members assigned by the Turkish Society of Cardiovascular Surgery, Cardio-Vascular-Thoracic Anaesthesia and Intensive Care Society, and Turkish Society of Cardiology. This book has been recently published to raise the awareness of PBM and to educate members of the Heart Team in cardiac surgery. ${ }^{[3]}$ This book, written in Turkish, is a synopsis of information in the latest literature and international guidelines.

In this report, you can find recommendations about all blood-conservation strategies using expressions such as 'should be used', 'is reasonable', 'may be used' or 'it is not recommended'. This judgment is achieved by assessing the effectiveness of the treatment according to the latest literature and guidelines.

\section{CLASSIFICATION OF STRATEGIES FOR BLOOD CONSERVATION}

In this report, each technique is classified according to the application period. This classification provides a better understanding and systematic approach for clinicians. Table 1 shows the classification of techniques.

\section{RISK IDENTIFICATION FOR TRANSFUSION AND BLEEDING}

\section{Transfusion}

Transfusion, related to bleeding or not, carries a risk for infective (viral diseases, pneumonia, wound infection) and non-infective (renal failure, TRALI, TACO, TRIM) complications. This effect on morbidity and mortality is strongly confirmed by many studies. ${ }^{[4]}$ Therefore, transfusion should be applied for the appropriate target at the right time. Instead of laboratory tests (hemoglobin [Hb] or hematocrit [Hct]), inadequate tissue oxygenation markers are suggested to make a decision for transfusion. ${ }^{[5]}$ To date, many risk scoring systems have been developed, and the most recent one is the ACTA-PORT which is useful to predict the number of packed cells to transfuse during cardiac surgery. ${ }^{[6-9]}$

\section{Bleeding}

Bleeding after cardiac surgery is seen in 2 to $9 \%$ of cases and increases the risk for morbidity and mortality up to six fold. ${ }^{[10,11]}$ The risk for bleeding should be identified and, then, preventive and blood 
Table 1. Blood conservative strategies classified according to application period

\begin{tabular}{lll}
\hline Preoperative & Intraoperative & Postoperative \\
\hline $\begin{array}{l}\text { Risk identification for } \\
\text { transfusion and bleeding }\end{array}$ & $\begin{array}{l}\text { Blood conservative } \\
\text { Surgical technique } \\
\text { Preoperative anemia; diagnosis and }\end{array}$ & $\begin{array}{c}\text { Management of bleeding } \\
\text { 1. Transfusion criteria }\end{array}$ \\
$\begin{array}{l}\text { Preoperative antithrombotic } \\
\text { drug management }\end{array}$ & Antifibrinolytics & $\begin{array}{c}\text { Viscoelastic test guided coagulopathy } \\
\text { treatment }\end{array}$ \\
$\begin{array}{l}\text { Preoperative coagulation test } \\
\text { Autologous blood donation }\end{array}$ & Acute normovolemic & Postoperative antithrombotic drug \\
& Hemodilution & management \\
& Heparin-protamine management & \\
Volume therapy & \\
& Minimally invasive extracorporeal & \\
circulation and techniques & \\
& Autotransfusion & \\
& Ultrafiltration & \\
\hline
\end{tabular}

conservative strategies should be planned before the operation. Until present, different risk scoring systems for bleeding have been used, but have not been widely accepted. Therefore, the common causes for bleeding should be recognized by the Heart Team (Table 2).

\section{Recommendations}

1. The risk score for transfusion (ACTA-PORT) should be calculated (predicted number of packed cells) preoperatively, and preventive strategies should be applied during the whole perioperative period.

2. The risk factors for bleeding should be examined preoperatively. The level of bleeding risk should be identified, and all preventive strategies should be planned, when necessary.

\section{PREOPERATIVE ANEMIA: DIAGNOSIS AND TREATMENT}

Anemia is a common comorbidity which occurs in 25 to $40 \%$ of patients undergoing elective cardiac surgery. ${ }^{[13,14]}$ Perioperative anemia and blood transfusion can be considered as preventable surgical risk factors, as both anemia and transfusion contribute to poor outcomes. ${ }^{[15]}$ Preoperative anemia should be defined, evaluated, and managed to minimize the use of blood products in patients undergoing cardiac surgery. It is considered, with the treatment of anemia, complications such as transfusion-related mortality and morbidity are reduced and long intensive care and hospital stay are shortened. ${ }^{[16,17]}$

Table 2. Risk factors for bleeding and re-operation for bleeding

\begin{tabular}{lll}
\hline Patient related risk factors & Procedure-related risk factors & Risk factors for re-operation for bleeding \\
\hline Age $(>70$ years $)$ & Surgeon & Age $(>70$ years $)$ \\
Female & Prolonged CPB time & Low BMI \\
Low BMI & Redo operation & High EuroSCORE \\
Preoperative anemia & Emergent surgery & Non CABG or combined procedures \\
Preoperative antithrombotic drug & High creatinine levels \\
Chronic renal failure & & \\
Liver failure & & \\
Diabetes mellitus & & \\
\hline
\end{tabular}

CPB: Cardiopulmonary bypass; BMI: Body mass index; CABG: Coronary artery bypass grafting. 
Irrespective of male or female gender, $\mathrm{Hb}$ levels below $13 \mathrm{~g} / \mathrm{dL}$ are considered anemia. ${ }^{[18]}$ All patients undergoing a major elective surgery should be evaluated for anemia. Iron deficiency is the most common cause of anemia in the perioperative period. Intravenous iron should be used as the first-line treatment option in patients who do not respond to oral iron or have iron intolerance, or surgery is planned within 6 weeks after the diagnosis of iron deficiency. ${ }^{[18,19]}$

\section{Recommendations}

1. The laboratory testing for anemia (iron, ferritin, transferrin saturation) should be evaluated preoperatively and surgery needs to be scheduled in this context.

2. In untreated anemia patients, it is reasonable to postpone elective surgery for the diagnosis and treatment of anemia.

3. Investigation of ferritin levels, even if the patient is not anemic, may be used in high-risk patients for bleeding.

4. In the treatment of preoperative anemia, $\mathrm{Hb}$ level should be targeted as $\geq 13 \mathrm{~g} / \mathrm{dL}$ for both genders.

5. Preoperative iron replacement:

- Oral iron replacement therapy is reasonable in case of iron deficiency, either anemic or nonanemic, if the procedure can be postponed for 6 to 8 weeks.

- Intravenous iron therapy should be used in patients who are scheduled for surgery less than 6 weeks or who do not respond to or tolerate oral iron therapy.

- In case of iron sequestration (non-anemic), preoperative erythropoietin therapy may be used in selected high-risk patients for bleeding.

- In case of anemia, combined iron replacement and erythropoietin treatment may be used preoperatively in selected patients.

6. Dietary supplements (such as vitamin B12, vitamin $\mathrm{D}$, folic acid) may be used in selected patients.

7. Routine preoperative red blood cell (RBC) transfusion is not recommended in case of anemia.

8. Iron replacement and erythropoietin treatment may be used in groups of patients who are scheduled for preoperative autologous blood donation (rare blood groups, insufficient blood stock, and alloimmunization, etc.).

\section{PREOPERATIVE ANTITHROMBOTIC DRUG MANAGEMENT}

\section{Recommendations for Antiplatelet Therapy}

1. The risk for thrombosis following percutaneous coronary intervention (PCI) should be identified preoperatively to optimize antithrombotic drug management. ${ }^{[20]}$

2. The thrombotic risk following PCI should be identified, irrespective of the stent type (bare metal stent [BMS] or drug-eluting stent [DES]) according to the time to surgery after stent implantation, angiographic features of the coronary lesions, and clinical characteristics of every individual patient. ${ }^{[21-24]}$

3. High thrombotic risk group comprises the patients having balloon angioplasty within 2 weeks, stent implantation within 3 months (particularly within the past month), and acute coronary syndrome (ACS) or complex PCI within 6 months. Intermediate risk includes balloon angioplasty between 2 to 4 weeks, stent implantation between 3 to 6 months, and ACS or complex PCI between 6 to 12 months. ${ }^{[25]}$

Preoperative use of acetylsalicylic acid (ASA) ${ }^{[26,27]}$

4. If cardiac surgery is elective and the risk for bleeding is high (complex or redo surgery, severe renal insufficiency, hematological disease, and hereditary thrombocyte dysfunction); ASA may be interrupted at least 5 days before surgery.

5. If cardiac surgery is urgent or emergent, the risk for bleeding is low or moderate, or the risk for thrombosis is moderate or high, ASA should not be discontinued before surgery.

Preoperative use of dual antiplatelet therapy $(D A P T)^{[26-29]}$

6. ASA should not be interrupted preoperatively.

7. Ticagrelor, clopidogrel and prasugrel should be interrupted 3, 5 and 7 days, respectively before surgery in patients who have an intermediate thrombotic risk (excluding low bleeding risk patients).

8. In case of a high thrombotic risk with a low bleeding risk, surgery can be performed without any interruption. If the bleeding risk intermediate or high, the patient should be evaluated by the Heart Team for the necessity of bridging therapy (Figure 1). 


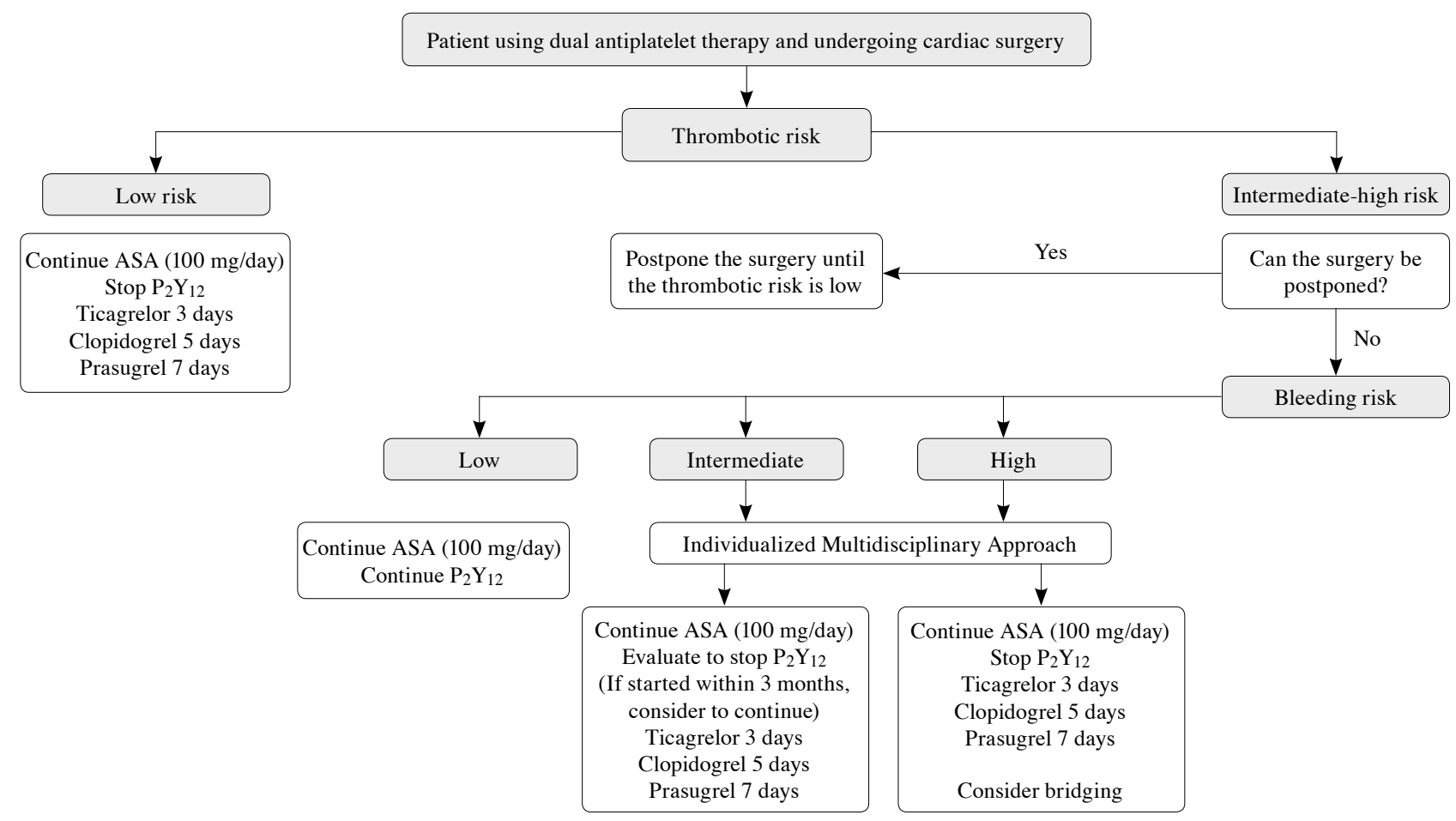

Figure 1. Preoperative management of dual antiplatelet therapy according to thrombotic and bleeding risk in cardiac surgery. ASA: Acetylsalicylic acid.

9. Bridging therapy with eptifibatide, tirofiban, and cangrelor may be used in patients with a high thrombotic and bleeding risk for cardiac surgery which cannot be postponed (Figure 2).

10. It is reasonable to use platelet function test to analyze the residual effect of $\mathrm{P}_{2} \mathrm{Y}_{12}$ inhibitors to optimize the time of surgery or to identify the risk for bleeding. ${ }^{[30-32]}$

\section{Recommendations for Anticoagulant Therapy}

1. The risk for thrombosis should be identified preoperatively to optimize anticoagulant drug management. The thrombotic risk assessment are based on the type of prosthetic heart valve, the position of valve, a history of cerebrovascular event due to valve thrombosis, $\mathrm{CHA}_{2} \mathrm{DS}_{2}$-VASc score, etiology of atrial fibrillation (AF) and thrombophilia. ${ }^{[29,33]}$

2. Thrombotic risk is associated with the indication of anticoagulation therapy.

3. Prosthetic mitral valve, tricuspid valve (including biological valve), aortic monoleaflet valve, and stroke/transient ischemic attack (TIA) within the past 6 months due to valve thrombosis constitute the high thrombotic risk for patients with prosthetic heart valves. The $\mathrm{CHA}_{2} \mathrm{DS}_{2}-$ VASc score 7-9, stroke/TIA within the past 3 months and AF due to rheumatic mitral valve disease and new venous thromboembolism, severe thrombophilia comprise the high-risk group.

4. Prosthetic aortic valve plus one risk factor (AF, stroke/TIA $>6$ months, diabetes mellitus $[\mathrm{DM}]$, congestive heart failure $[\mathrm{CHF}]$, and age $>75$ years) for prosthetic heart valve, $\mathrm{CHA}_{2} \mathrm{DS}_{2}$-VASc score 5-6, and stroke/TIA history within the past 3 months due to AF and venous thromboembolism within the past 3 to 12 months, and non-severe thrombophilia for venous thromboembolism indicate an intermediate risk.

5. Prosthetic aortic valve without any risk factor, $\mathrm{CHA}_{2} \mathrm{DS}_{2}$-VASc score 1-4 without stroke/ TIA, and venous thromboembolism more than 12 months prior constitute a low risk.

\section{Preoperative use of Vitamin $\mathrm{K}$ antagonist (VKA) $)^{[26,34,35]}$}

1. VKA should be stopped at least 5 days before cardiac surgery and bridged with low-molecularweight heparin (LMWH) or unfractionated 


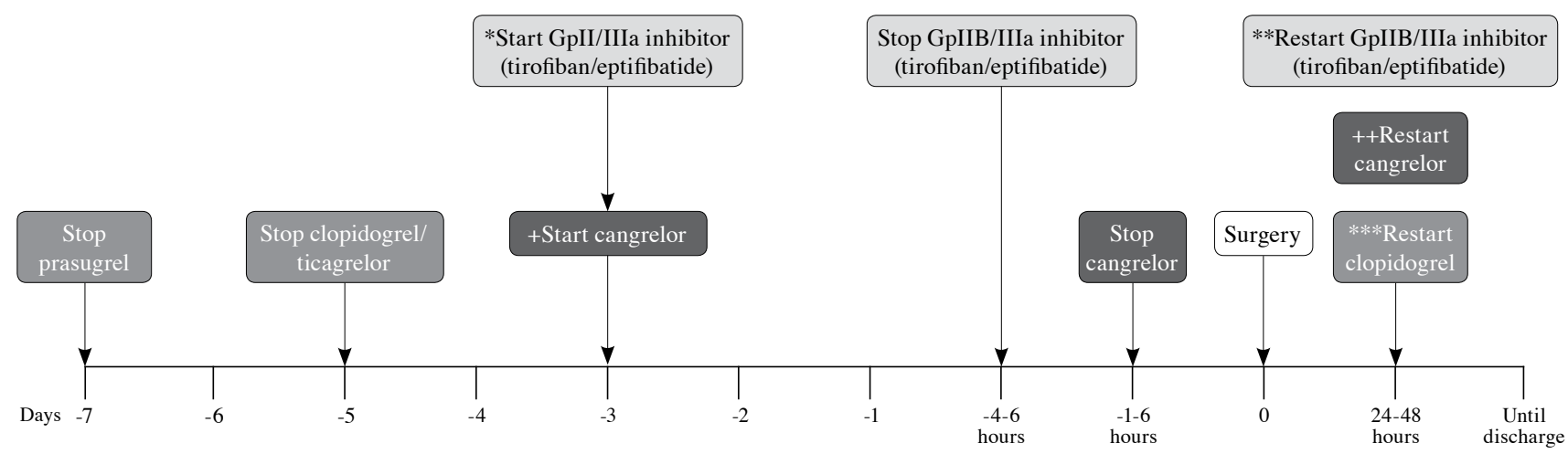

Figure 2. Perioperative management of dual antiplatelet therapy in cardiac surgery.

* After discontinuation of $\mathrm{P}_{2} \mathrm{Y}_{12}$ within 72 hours without bolus dose;

Tirofiban: $\mathbf{0 . 1} \mu \mathrm{g} / \mathrm{kg} / \mathrm{min}$ (If creatinine clearance $<50 \mathrm{~mL} / \mathrm{min} 0.05 \mu \mathrm{g} / \mathrm{kg} / \mathrm{min}$ );

Eptifibatide: $2.0 \mu \mathrm{g} / \mathrm{kg} / \mathrm{min}$ (If creatinine clearance $<50 \mathrm{~mL} / \mathrm{min} 1.0 \mu \mathrm{g} / \mathrm{kg} / \mathrm{min}$ );

+ After discontinuation of $\mathrm{P}_{2} \mathrm{Y}_{12}$ within 72 hours without bolus dose;

$\mathbf{0 . 7 5} \mu \mathrm{g} / \mathrm{kg} / \mathrm{min}$ (No need to dose adjustment in renal failure minimum 48 hours to maximum 7 days)

** If no oral intake

++ If no oral intake

*** Within 24-48 hours when oral intake starts, clopidogrel should be given in $75 \mathrm{mg} /$ day maintenance dose following $300-600 \mathrm{mg}$ bolus dose. Prasugrel and ticagrelor are not recommended.

heparin (UFH) in patients with a high thrombotic risk (Figure 3).

2. Patients with a prosthetic aortic valve plus at least one risk factor should be considered a high thrombotic risk and managed accordingly. Other patients in the intermediate- and low-risk group should undergo cardiac surgery with VKA interruption 5 days before surgery without bridging.

3. In case of an emergent surgery, prothrombin complex concentrate (PCC) can be preferred to fresh frozen plasma (FFP) to reverse the effect of VKA and to prevent complications due to transfusion. ${ }^{[36-38]}$

\section{Preoperative Use of Direct Oral Anticoagulants (DOACs) ${ }^{[39]}$}

4. DOACs are rapid-acting drugs, and bridging is not recommended, if the timing is optimal.

5. The time of discontinuation of dabigatran should be managed (48 to 96 hours) according to the creatinine clearance levels (Figure 3).

6. The time of discontinuation of rivaroxaban, apixaban, and edoxaban is 48 hours before cardiac surgery, irrespective of the creatinine clearance levels.

7. In case of an emergent surgery, it is reasonable to use idarucizumab to reverse the effect of dabigatran. ${ }^{[40,41]}$
8. In case of an emergent surgery, it is reasonable to use Andexanet Alfa to reverse the effect of apixaban and rivaroxaban. ${ }^{[38,42,43]}$

\section{PREOPERATIVE COAGULATION TEST}

An important component of preoperative preparation is the patient's coagulation status. The first and most important way to evaluate coagulation status is to question the standardized history of personalized or familial bleeding. Patients' history (including the patients' and the families' bleeding history) and a careful preoperative physical examination are essential to identify pre-existing hemorrhagic disorders. ${ }^{[44]}$ Coagulation tests should be performed in patients with an acute pathology which may cause hemorrhage. ${ }^{[45]}$ In addition to standard laboratory tests (prothrombin time $[\mathrm{PT}]$ and activated partial thromboplastin time [aPTT]), viscoelastic tests (VETs) have also an important role in perioperative (pre-, intra-, and postoperative) evaluation and treatment of coagulation status. Fibrinogen level is the only test which has been shown to be a predictor of bleeding in many recent guidelines. ${ }^{[2]}$ Platelets should be functionally evaluated in selected patients besides thrombocytopenia.

\section{Recommendations}

1. The use of routine coagulation tests for the prediction of perioperative bleeding is not 


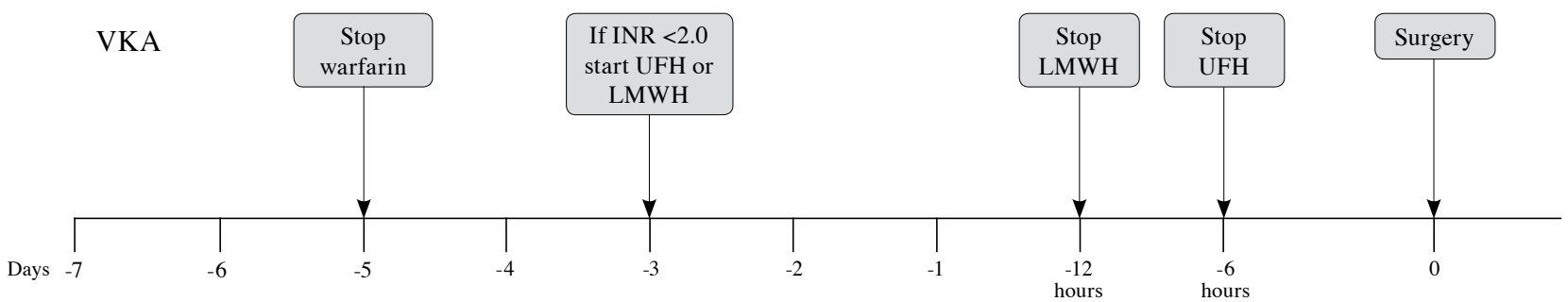

DOAC

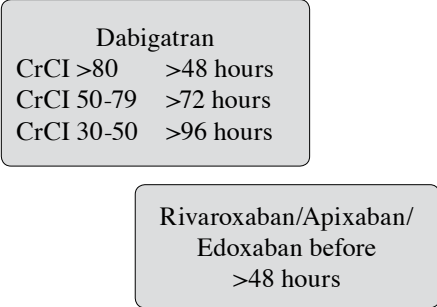

Figure 3. Perioperative management of oral anticoagulant therapy in cardiac surgery.

Bridging algorithm for the patients using oral anticoagulation and undergoing cardiac surgery.

VKA: Vitamin K antagonist; INR: International normalized ratio; UFH: Unfractionated heparin; LMWH: Low molecular weight heparin; DOAC: Direct oral anticoagulant; CrCI:

Creatinine clearance.

recommended in non-selected patients prior to surgery and other invasive procedures.

2. A standardized bleeding questionnaire should be used for screening the perioperative bleeding risk. It is reasonable to perform VET and/or standard coagulation test (SCT) in the following patients:

i. Positive bleeding history

ii. Surgical procedure with a high risk for bleeding

iii. Presence of comorbidities with a high risk for bleeding (such as disseminated intravascular coagulation, sepsis, and liver disease)

3. Routine testing of platelet function is not recommended. It is reasonable to use if,

i. Hemorrhage is not diagnosed by SCT and VET.

ii. A potent $\left(\mathrm{P}_{2} \mathrm{Y}_{12}\right.$ inhibitors) antiplatelet drug is used.

\section{AUTOLOGOUS BLOOD DONATION}

Preoperative autologous donation (PAD) is known, but not commonly used as blood conservation strategy. Through the PAD, the patient is protected against febrile and non-febrile transfusion reactions, alloimmunization, and graft-versus-host disease (GVHD). However, the risk for infection or hemolysis persists, and the risk for transfusion due to anemia induced by donation and availability of autologous blood is increased with a high cost. On the other hand, PAD should be limited to healthy individuals with a long life expectancy requiring intense blood transfusion or those without cross-match compatible blood. The eligibility criteria for PAD are good health condition, being tolerant to iron replacement and surgery with the risk for bleeding more than 500 to $1000 \mathrm{~mL}$. It is contraindicated in case of cardiovascular risk factors (unstable angina, recent myocardial infarction, heart failure, aortic stenosis, angina at rest, or TIA), organ dysfunction, and active infection.

\section{Recommendations}

1. Routine use of PAD is not recommended, as PAD is associated with lower preoperative $\mathrm{Hb}$ levels leading to higher amounts of transfusion. ${ }^{[46-48]}$

2. PAD may be used in case of rare blood type, or if identification of alloantibody is not possible and cross-match compatible blood is not available. ${ }^{[49,50]}$

\section{BLOOD CONSERVATIVE SURGICAL TECHNIQUES}

Operative technique is one of the most important steps in the prevention of morbidity related to bleeding and transfusion. The decision should be made by the multidisciplinary Heart Team. Hemodilution and coagulopathy due to CPB are prevented by off-pump cardiac surgery which may reduce transfusion. 
However, meta-analyses and randomized trials have not reached a final judgment about this issue. ${ }^{[1,52]}$ Therefore, it is recommended only in selected patients in accordance with the recent guidelines. ${ }^{[2]}$ Minimally invasive approaches cause less surgical trauma which reduce bleeding. Most of studies have concluded that the use of blood products would be restricted by minimally invasive surgery. ${ }^{[53-55]}$

\section{Recommendations}

1. The decision of the multidisciplinary team (a surgeon, cardiologist, anesthesiologist, and perfusionist) is strongly recommended in terms of treatment strategy, incision, and operative technique to prevent complications due to bleeding and transfusion.

2. Off-pump surgery may be preferred to reduce perioperative use of blood products, if optimal surgical treatment is provided.

3. Minimally invasive techniques (minithoracotomy, mini-sternotomy transcatheter aortic valve implantation [TAVI], other transcatheter techniques) may be performed to reduce perioperative use of blood products, where applicable.

\section{THE USE OF FRESH WHOLE BLOOD (FWB)}

The FWB identifies the donor blood stored at room temperature less than 24 hours after donation. ${ }^{[56]}$ Hemostatic properties of FWB gradually decrease by lowering FV and FVIII levels, and viable platelets yield in course of time. In addition, the increase in the extracellular potassium and lactate and the decrease in glucose and $\mathrm{pH}$ levels during the storage of whole blood result in metabolic imbalances after transfusion. ${ }^{[57,58]}$

Although, several clinical studies have demonstrated the superiority of FWB to reconstituted blood which is composed of FFP, RBC, and single donor platelet concentrate (dPC) units in terms of bleeding control, overall studies have concluded that the only advantage of FWB against reconstituted blood is less donor exposure. ${ }^{[57-59]}$

\section{Recommendation}

1. The use of FWB is not recommended in cardiac surgery, if blood components are avalibale.

\section{ANTIFIBRINOLYTICS}

Antifibrinolytics (tranexamic acid [TXA], Epsilon-aminocaproic acid [EACA], and aprotinin) are used to reduce blood loss, blood transfusion, and the need for reoperation in cardiac surgery. ${ }^{[60,61]}$ This triple effect has been demonstrated for aprotinin and TXA. ${ }^{[60,62]}$ However, the effect of EACA on the reduction of reoperation has not been demonstrated, yet. ${ }^{[60]}$

The multi-center Aspirin and Tranexamic Acid for Coronary Artery Surgery (ATACAS) study showed that blood transfusion requirement $(\mathrm{p}<0.001)$ and reoperation rate $(1.4 \%$ and $2.8 \%, \mathrm{p}=0.001)$ were lower in the TXA group, despite increased neurological events such as convulsions. ${ }^{[62]}$ Several meta-analyses also demonstrated that aprotinin reduced the need for reoperation and blood transfusion. ${ }^{[60]}$ However, this drug has not been licensed, except for some countries, due to its adverse effect on cardiovascular events and mortality. Thus, care should be taken to ensure that it is approved by the local authority and the balance of benefit/harm should be considered. Although there is a limited number of studies comparing EACA to other antifibrinolytic agents, there are meta-analyses showing similar effects to other antifibrinolytic agents. ${ }^{[63]}$

\section{Recommendation}

1. Antifibrinolytics should be used to reduce bleeding and transfusion. ${ }^{[60,62,64]}$

\section{ACUTE NORMOVOLEMIC HEMODILUTION (ANH)}

Acute normovolemic hemodilution is one of the strategies to decrease the need for allogeneic blood transfusion in cardiac surgery. It is commonly used, reliable, easy-to-apply, and low-cost technique. The $\mathrm{ANH}$ has been shown to regulate microcirculation by reducing blood mass, blood cell damage, and preserving organ functions by reducing the inflammatory response. ${ }^{[65]}$ The amount of transfusion has been reduced by 18 to $90 \%$ through $\mathrm{ANH}{ }^{[66]}$

\section{Recommendations}

1. ANH may be used to reduce perioperative transfusions in selected cases. ${ }^{[67]}$

2. It is reasonable to use $\mathrm{ANH}$ in patients with autologous blood transfusion, rare blood group, alloantibody positivity, and refusing allogenic transfusion for special reasons. ${ }^{[67]}$

3. ANH is not recommended:

- In the presence of severe anemia $(\mathrm{Hb}<11 \mathrm{~g} / \mathrm{dL}$ or Hct $<33 \%$ ) or platelet dysfunction. ${ }^{[67]}$

- Coronary artery disease (critical stenosis, unstable angina, left ventricle dysfunction). ${ }^{[68]}$ 
- In the presence of severe pulmonary disease, impaired renal function and hepatic dysfunction. ${ }^{[68]}$

4. Each center should establish their own protocol (patient selection, vascular access, ANH volume, fluid to be replaced, blood collection, and storage) in ANH applications.

\section{HEPARIN-PROTAMINE MANAGEMENT}

Optimal anticoagulation during $\mathrm{CPB}$ and its adequate neutralization after $\mathrm{CPB}$ is important to maintain the balance between thrombosis and bleeding in cardiac surgery. Less anticoagulation may cause thrombi, more consumption of coagulation factors, and vice versa, it may cause bleeding and consumption of coagulation factors. For heparin, dosing, its application, measurement of anticoagulation, appropriate reversal by protamine, alternatives of heparin are the main challenges during $\mathrm{CPB}$.

\section{Recommendations}

1. The bolus administration of UFH based on the body weight (300 to $400 \mathrm{IU} / \mathrm{kg}$ ) is reasonable to ensure adequate anticoagulation. ${ }^{[69]}$

2. The efficacy of anticoagulation should be measured by therapeutic functional test or maximum activated clotting time (ACT) at regular intervals before and during $\mathrm{CPB}$. The ACT should be kept for more than $480 \mathrm{sec}$ during CPB. ${ }^{[69,70]}$

3. Heparin concentration analysis may be used in addition to $\mathrm{ACT} \cdot{ }^{[71]}$

4. If anticoagulation is inadequate before $\mathrm{CPB}$, despite additional doses of heparin, FFP transfusion or antithrombin III infusion may be used. ${ }^{[72]}$

5. Protamine dose adjustment according to heparin level is reasonable to prevent bleeding and to minimize blood product use. ${ }^{[71]}$

6. It is reasonable to provide a protamine/heparin ratio of $1: 1$. The ratio above 2.6:1 is associated with platelet dysfunction, coagulopathy, and bleeding. ${ }^{[70]}$

7. In patients requiring high-dose UFH use, lowdose protamine infusion may be used for 6 hours after CPB to prevent heparin rebound. ${ }^{[73]}$

8. The adverse effects of protamine (i.e., vascular collapse, pulmonary hypertension, and anaphylaxis) should be recognized and resuscitative care should be planned. ${ }^{[74]}$

9. In case of heparin-induced thrombocytopenia
(HIT) diagnosed based on functional serum tests, it is reasonable to postpone (about 2 to 3 months) elective surgery requiring $\mathrm{CPB}$.

10. In case of an emergent surgery, it is reasonable to use bivalirudin as an alternative to heparin. Its efficacy can be monitored by the ecarin clotting time (ECT). The reversal of its effect by any antidote is not possible, which may cause bleeding after CPB and require additional hemostatic strategy. ${ }^{[70]}$

\section{HEPARIN-INDUCED THROMBOCYTOPENIA}

Heparin-induced thrombocytopenia is an adverse drug reaction of heparin which may result in potentially fatal clinical entities. It is not uncommon and caused by risk factors similar to cardiac surgery. ${ }^{[75,76]}$ It develops within 1 to 2 weeks after heparin, and antibodies to the heparin-platelet factor 4 complex play a key role in the clinical status of the patient. ${ }^{[2]}$ The risk for HIT development is independent of the type, dose, and route of administration of heparin. Clinical picture includes thrombocytopenia and both arterial and venous thrombosis due to activation of platelets. The 4T score should be assessed for the likelihood of HIT by thrombocytopenia, time of platelet decline, presence of thrombosis, and other causes of thrombocytopenia. ${ }^{[77]}$ Discontinuation of heparin alone is not sufficient to reduce the risk for thrombosis, and non-heparin anticoagulant treatment is necessary. ${ }^{[78-80]}$

If cardiac surgery cannot be postponed, bivalirudin or argatroban may be used as an alternative for anticoagulation during CPB. However, the use of non-heparin anticoagulants (bivalirudin, argatroban, danaparoid, fondaparinux, or DOACs) have not been approved for use in the treatment of acute HIT. The treatment agent and application amounts to be selected should be based on the patient-specific evaluation.

\section{Recommendations}

1. 4T score should be calculated in case of HIT suspicious clinical findings such as thrombocytopenia accompanied by a thrombotic event. ${ }^{[77]}$

- If score is 0-3, heparin treatment is regulated according to the indication and non-heparin anticoagulants are discontinued, if possible.

- If score is $\geq 4$, heparin is discontinued and non-heparin anticoagulant is initiated. 
If immunological assay yields negative results, it is treated as a low $4 \mathrm{~T}$ score. Otherwise (in case of positivity), a functional assay may be performed to confirm.

- If the score is $6-8$, the probability of the diagnosis is high, even the functional test is negative.

2. In case of elective cardiac surgery requiring heparin, it is reasonable to postpone the procedure until HIT antibodies become negative.

3. If cardiac surgery cannot be postponed, it is reasonable to use bivalirudin or argatroban as an alternative for anticoagulation during CPB.

4. In case of HIT, the use of heparin (UFH or LMWH) should be avoided in the perioperative period.

5. Non-heparin anticoagulants may be used in case of HIT, even if it is off-label use.

\section{VOLUME THERAPY}

The aim of fluid (crystalloid or colloid) therapy in cardiac surgery is to maintain adequate blood pressure, cardiac output, tissue perfusion, and oxygenation. A consensus has not yet been reached upon on the optimal choice of fluids, either crystalloid or colloid. However, it is known that hemodilution is caused by priming and volume resuscitation, and both increase the use of blood products. ${ }^{[81]}$

Crystalloid solutions are routinely used in cardiac surgery, since they cause lower rates of coagulopathy, infection, and anaphylaxis with a lower cost. However, high-volume normal saline solution $(0.9 \%)$ has been shown to alter serum osmolarity, increase the blood product use, cause hyperchloremic acidosis, and postoperative acute renal failure. Stable isotonic solutions such as ringer lactate or ringer solution are therefore recommended. ${ }^{[82]}$

The most commonly used colloid solutions are hydroxyethyl starch (HES) solutions, albumin and gelatin which are more effective to expand intravascular volume. ${ }^{[83,84]}$ However, the main disadvantages include impaired renal function, need for renal replacement therapy, tendency to bleed, and an increased risk for mortality. There are conflicting results in the literature and yet a single consensus has not been established for the use of colloid solutions. ${ }^{[85-87]}$ Nonetheless, newgeneration HES solutions seem to be safer in terms of coagulopathy and renal complications. ${ }^{[88]}$

\section{Recommendations}

1. The target is the hemodynamic stability in the perioperative period provided by volume therapy. ${ }^{[89]}$

2. Preoperative risk factors, hemodilution, high Hct values, and coagulation status should be considered during volume therapy in the perioperative period. ${ }^{\text {[72] }}$

3. In addition to fluid selection, timing, monitoring (particularly dynamic, transesophageal echocardiography), and evaluation of hemodynamics are crucial. ${ }^{[72]}$

4. There is no advantage in using HES as the prime solution to reduce bleeding and blood product use. ${ }^{[90]}$

5. Hemodilution should be avoided to reduce bleeding and blood transfusion. ${ }^{[81]}$

6. The use of new-generation HES solutions are not recommended to reduce hemorrhage, although limitation of hemodilution is reasonable to reduce bleeding and transfusion. ${ }^{[72]}$

7. The use of HES solutions in volume therapy should be restricted to prevent renal complications and reduce mortality. ${ }^{[91]}$

8. Stable and isosmotic electrolyte solutions may be used, if crystalloid solutions are preferred. ${ }^{[92]}$

9. The colloid solution use should not exceed $30 \mathrm{~mL} / \mathrm{kg}$ per day; new-generation HES solutions or gelatin may be preferred, if colloids are to be used. ${ }^{[93]}$

10. In the postoperative period, balanced solutions (ringer, ringer lactate) should be preferred as the maintenance fluid therapy. ${ }^{[82]}$

11. FFP should not be used for volume extension. ${ }^{[72]}$

\section{MINIMALLY INVASIVE EXTRACORPOREAL CIRCULATION AND STRATEGIES}

Hemodilution, excess activation of coagulation system, loss of platelets, and its function are associated with systemic inflammatory syndrome caused by CPB which increase the risk for transfusion in the perioperative period. ${ }^{[94-96]}$

The Minimal Invasive Extracorporeal Minimally Invasive Extracorporeal Circulation (MiECC) defines essentially closed, shortened, biocompatible circuit without venous reservoir which requires less prime volume and anticoagulation. ${ }^{[97]}$ Metaanalyses and studies have shown the beneficial 
effect of the use of MiECC in terms of packed red cell transfusion. ${ }^{[98-100]}$ Retrograde or antegrade autologous priming techniques are also used to reduce hemodilution during CPB. This beneficial effect has been confirmed in several studies and recommended by the recent guidelines. ${ }^{[72,101,102]}$

\section{Recommendations}

1. The use of MiECC is reasonable to decrease the risk for transfusion.

2. The RAP and AAP can be used to reduce hemodilution and to decrease the amount of transfusion.

\section{AUTOTRANSFUSION}

In cardiac surgery, blood taken from the mediastinal shed and remaining into the CPB circuit are collected, processed, and infused to the patient intra- and postoperatively through the autotransfusion techniques. ${ }^{[72,103]}$ As a result, allogenic blood transfusion, particularly RBC transfusion, can be reduced by the cellsalvage system. ${ }^{[72,103]}$ Besides, systemic inflammatory response related to $\mathrm{CPB}$ may cause postoperative organ dysfunction and complications which can be reduced by autotransfusion. ${ }^{[104]}$ The use of autotransfusion system improve the anti-inflammatory cytokine/proinflammatory cytokine ratio. ${ }^{[105]}$

\section{Recommendations}

1. It is reasonable to use autotransfusion (cellsalvage system) to reduce transfusion, particularly in high-risk patients.

\section{ULTRAFILTRATION (UF)}

Hemodilution during $\mathrm{CPB}$ may result in an increased total body water, interstitial edema of vital organs, hypoxia, hypotension, coagulopathy, renal dysfunction, myocardial and cerebral ischemia, and even mortality. Ultrafiltration is a hemoconcentration technique which filtrates the plasma from blood via semi-permeable membrane which is used as a blood conversation strategy in cardiac surgery. The beneficial effects of UF in cardiac surgery patients are uncertain and, although some studies have shown a benefit, some others have provided controversial results. ${ }^{[106]}$ Several studies have also demonstrated reduced RBC transfusions with the use of UF. In a randomized-controlled study from Brazil, modified ultrafiltration (MUF) groups had reduced chest tube drainage compared to control group after 48 hours and the Hct levels were higher and transfusion requirement was less in the MUF group. ${ }^{[107]}$ Metaanalysis conducted by Boodhwani et al. ${ }^{[108]}$ found a benefit of UF in lower rates of postoperative bleeding and blood transfusions. Mongero et al. ${ }^{[109]}$ analyzed a total of 40,650 (propensity-matched) adult cardiac surgery cases for a 61-month period and concluded that UF was not associated with a reduction of risk for $\mathrm{RBC}$ transfusion during cardiac surgery.

\section{Recommendations}

1. There is no adequate evidence to recommend the routine use of UF as a blood conversation technique or to decrease postoperative bleeding in adult cardiac surgery.

2. The UF, particularly MUF, may be used in selected patients such as volume overload or excessive use of crystalloid cardioplegia.

\section{HEMOSTATIC AGENTS}

\section{A. Fresh Frozen Plasma}

\section{Recommendations}

1. FFP should not be used prophylactically to reduce blood loss or reduce the need for blood products in cardiac surgery. ${ }^{[110,111]}$

2. The use of FFP is reasonable to decrease bleeding due to coagulation factor deficiency and the need for blood transfusion, particularly by the VET guidance.

3. FFP may be used to reverse the effect of oral VKAs preoperatively. ${ }^{[110,111]}$

\section{B. Factor XIII}

Factor XIII (FXIII) is a coagulation factor acting at the end of the coagulation cascade, provide a tight and strong clot formation by cross-linking fibrin monomers. There is no evidence that the use of FXIII which reduces bleeding, the need for blood products, and reoperation for bleeding. ${ }^{[112]}$

\section{Recommendation}

1. Prophylactic use of FXIII is not recommended, but may be beneficial in selected patients with postoperative plasma FXIII level less than $70 \%$ of normal value. ${ }^{[12]}$

\section{Fibrinogen}

In cardiac surgery, hypofibrinogenemia is a common coagulopathy associated with CPB, hemodilution, and bleeding which strongly causes bleeding. ${ }^{[113]}$

\section{Recommendations}

1. Fibrinogen concentrate should not be used prophylactically to reduce bleeding or the need for transfusion. ${ }^{[114]}$ 
2. It is reasonable to use fibrinogen concentrate in case of bleeding related to hypofibrinogenemia (lower than 1.5-2 g/dL). ${ }^{[15]}$

\section{Prothrombin complex concentrate}

Prothrombin complex concentrate comprises coagulation factors (Factors II, VII, IX, X) whose production is vitamin $\mathrm{K}$-dependent. It ( 4 factors or activated form) is used to treat bleeding related to VKA or coagulation factor deficiency, and to reverse VKA effect in case of an emergent surgery. In patients with elevated international normalized ratio (INR) values (>4-5) under VKA treatment, it is aimed to reverse the effect of VKA with PCC or FFP, when an urgent surgical intervention is required. ${ }^{[16]}$

\section{Recommendations}

1. It is reasonable to use PCC in case of bleeding associated with VKA therapy or coagulation factor deficiency.

2. PCC may be preferred to FFP with the intent of rapid and effective reversal of VKA to prevent complications related to FFP. ${ }^{[16]}$

\section{E. Desmopressin}

Desmopressin (1-deamino-8-D-arginine vasopressin; DDAVP) is a vasopressin analog which induces the von Willebrand factor (vWF) release from endothelial cells. ${ }^{[17]}$ Although it has been argued that perioperative DDAVP use in cardiac surgery may lead to a slight decrease in the postoperative bleeding, this effect has been found to be more prominent in patients with platelet dysfunction or preoperative ASA use.

\section{Recommendation}

1. Desmopressin should not be used prophylactically to reduce blood loss. However, in patients with bleeding related to platelet dysfunction (inherited or acquired), the use of DDAVP is reasonable to reduce blood loss and transfusion requirements. ${ }^{[118]}$

\section{F. Recombinant Factor VIIa}

After tissue damage, Factor VIIa (FVIIa), formed by the effect of tissue factor, plays a role in the coagulation cascade by activating Factor X. Although it is suggested to use in the management of hemorrhages refractory to conventional methods in adult and pediatric cardiac surgery, there are some reports of increased thromboembolic events. ${ }^{[119-121]}$

\section{Recommendation}

1. FVIIa should not be used prophylactically to reduce bleeding in cardiac surgery.
2. FVIIa may be used in case of life-threatening hemorrhage refractory to conventional hemostatic methods. ${ }^{[120]}$

\section{G. Topical hemostatic agents (THAs)}

Topical hemostatic agents can be used to support the coagulation system in case of bleeding which cannot be controlled by conventional methods. ${ }^{[122]}$ These agents are classified according to characteristics as active (containing anti-bleeding agents) and passive (without anti-bleeding agents), or both.

\section{G.1. Active THAs}

Active THAs induce coagulation system by stimulating conversion of fibrinogen to fibrin at the site of bleeding via a high concentration of thrombin. ${ }^{[123]}$

\section{Recommendation}

1. The use of human-derived thrombin is reasonable in case of a high risk for bleeding in surgical sites. $^{[124]}$

\section{G.2. Passive THAs}

Passive THAs (collagen, cellulose, gelatin, and polysaccharides) do not contain coagulation factors, but have physical properties which lead to compression and platelet aggregation. ${ }^{[125]}$

\section{Recommendation}

1. The routine use of passive THAs in cardiac surgery is not recommended, although it may be used in case of bleeding from anastomosis and suture sites in patients with a high risk for transfusion. ${ }^{[126]}$

\section{G.3. Fibrin sealants}

Fibrin sealants contain fibrinogen and thrombin, leading to clot formation in the bleeding site. ${ }^{[127]}$

\section{Recommendation}

1. The use of fibrin sealants is reasonable in case of bleeding which arises from the needle hole in cardiac and aortic surgery. ${ }^{[126]}$

\section{MANAGEMENT OF BLEEDING}

\section{Transfusion Criteria}

Cardiac surgery carries a high risk for transfusion; however, transfusion should be administered for therapeutic, but not preventive purposes. ${ }^{[128]}$ Transfusion criteria may vary according to personal approaches and decisions, which is not based on scientific evidence. The following transfusion principles should be adopted: 
i. Transfusion should be applied in case of acute blood loss, hypoxia due to anemia, and coagulopathy causing bleeding.

ii. The balance between benefit/harm should be considered before transfusion.

iii. Laboratory values are not a trigger for transfusion.

iv. Transfusion should be applied, if there is a sufficient amount of knowledge and equipment to treat complications.

v. Patients need to be monitored during transfusion.

\section{Triggers for Packed Red Cell}

1. In case of $\mathrm{Hb} \geq 10 \mathrm{~g} / \mathrm{dL}$ or $\mathrm{Hct} \geq 30 \%$, transfusion should not be applied. ${ }^{[129]}$

2. In case of $\mathrm{Hb} \geq 8 \mathrm{~g} / \mathrm{dL}$ or $\mathrm{Hct} \geq 24 \%$, transfusion should be avoided unless;

a. An emergent surgery

b. Acute coronary syndrome

c. The need for high-dose inotropes or mechanical circulatory support

d. Venous oxygen saturation below $65 \%$

e. Arterial blood lactate level above $4.0 \mathrm{mmol} / \mathrm{L}$

f. Inadequate global body perfusion

g. Massive bleeding

h. End-organ ischemia (myocardial ischemia, stroke, or anuria)

3. In case of $\mathrm{Hb} 7$ to $8 \mathrm{~g} / \mathrm{dL}$ or Hct 21 to $24 \%$, transfusion may be considered, if there is low oxygen delivery to tissues. ${ }^{[128]}$

4. In case of $\mathrm{Hb}$ below $7 \mathrm{~g} / \mathrm{dL}$, transfusion is reasonable. ${ }^{[129]}$

5. In case of Hb below $6 \mathrm{mg} / \mathrm{dL}$, transfusion should be done.

\section{Fresh frozen plasma}

1. FFP should not be used to prevent bleeding or to expand intravascular volume. ${ }^{[130]}$

2. FFP should not be considered as the first-line therapy, if coagulopathy can be treated by VKA dose adjustment or vitamin $\mathrm{K}$.

3. FFP should not be used in case of coagulopathy without bleeding. ${ }^{[131]}$

4. FFP may be used in case of coagulopathy due to massive transfusion or major surgery. ${ }^{[12,131,132]}$

5. FFP may be used in case of bleeding due to coagulation factor deficiency, when fractionated blood products are unable to be obtained. ${ }^{[12,131,132]}$
6. FFP may be used in case of bleeding due to VKA therapy, when PCC is not available. ${ }^{[12]}$

7. The use of PCC (4-factors or activated form) is reasonable, if emergent reversal of VKA is needed. ${ }^{[12]}$

8. FFP can be used empirically or level-guided, in case of antithrombin III deficiency. ${ }^{[72,131,133]}$

9. In case of bleeding, off-label use of PCC may be considered as an alternative to FFP.

\section{Platelet}

Transfusion is reasonable:

1. If the platelet count is below $50 \times 10^{9} / \mathrm{L}$ in patients with bleeding

2. If thrombocytopenia due to massive transfusion is present

3. If thrombocytopenia due to disseminated intravascular coagulopathy is present. ${ }^{[72,133,134]}$

\section{Cryoprecipitate}

1. The use of cryoprecipitate is reasonable in case of bleeding accompanied by low (below 1.5 to 2 $\mathrm{g} / \mathrm{dL}$ ) fibrinogen levels. ${ }^{[135]}$

2. VET-guided use of cryoprecipitate is reasonable in case of bleeding.

3. Fibrinogen concentrate can be used instead of cryoprecipitate, if available.

\section{Viscoelastic test-Guided Coagulopathy Treatment}

Bleeding due to coagulopathy has worse consequences than surgical causes. ${ }^{[136]}$ The treatment of coagulopathy under the VET guidance may decrease the use of blood products and may improve clinical outcomes. ${ }^{[136-140]}$

\section{Recommendations}

1. VET-guided coagulopathy treatment is reasonable in case of bleeding or in selected patients with a high risk for bleeding.

2. The routine use of VET is not recommended in cardiac surgery.

3. Easy access, service 24/7, professional evaluation, and algorithmic application should be provided for effective use of VET.

4. Suggested treatment algorithms for thromboelastography (TEG) and rotational thromboelastometry (ROTEM) are presented in the book..$^{[3]}$

\section{Re-Exploration for Bleeding}

Bleeding, re-exploration and transfusion, alone or combined, affect the worst outcomes in cardiac 
surgery. ${ }^{[1]}$ The rate of re-exploration is about 2 to $8 \%$ and the major causes are surgical sites..$^{[1,141,142]}$ Therefore, early diagnosis of surgical bleeding, and emergent and appropriate correction is critical to prevent complications related to bleeding and blood products.

\section{Recommendations}

1. Meticulous surgery should be performed to prevent bleeding.

2. The team (a surgeon, intensive care specialist, and nurse) needs to be aware to keep chest tubes open. Active drainage systems may be used for this purpose. ${ }^{[143]}$

3. The team (a surgeon, intensive care specialist, and nurse) needs to be aware about hemodynamic changes related to bleeding.

4. Recommended amount of bleeding for re-exploration:

- Over $300 \mathrm{~mL} / \mathrm{h}$ within the first hour

- Over $250 \mathrm{~mL} / \mathrm{h}$ within the first 2 hours

- Over $200 \mathrm{~mL} / \mathrm{h}$ within the first 3 hours or total $750 \mathrm{~mL}$

- Massive bleeding

- Cardiac arrest accompanied by bleeding

- Cardiac tamponade.

5. Early re-exploration (within the first 12 hours) should be done in case of persistent drainage. ${ }^{[144,145]}$

6. In case of massive bleeding or bleeding associated cardiac arrest, re-exploration may be done in the intensive care unit.

\section{POSTOPERATIVE ANTITHROMBOTIC DRUG MANAGEMENT}

Medical treatment plays a key role for the success of perioperative and long-term care in cardiac surgery which reduces morbidity and mortality. ${ }^{[26]}$ Postoperatively, antiplatelet and anticoagulant therapy is crucial to prevent ischemic events, arrhythmias and to manage thromboembolic risk factors. ${ }^{[146]}$ However, these agents may increase the risk for late bleeding complications. Therefore, appropriate use of antiplatelet or anticoagulant agents should be recognized by the Heart Team..$^{[147]}$

\section{Recommendations}

\section{Acetylsalicylic Acid}

1. Acetylsalicylic acid should be restarted within 24 hours (6 hours, if possible) after coronary artery bypass grafting (CABG), when early bleeding is not significant. ${ }^{[148]}$

2. It is reasonable to restart within 24 hours after surgery, when there is no concern about bleeding in patients undergoing non-coronary cardiac surgery with a preoperative indication for ASA.

\section{Dual Antiplatelet Therapy}

1. It is reasonable to restart DAPT after CABG as soon as it is considered safe in patients with ACS. In patients with a high risk for ischemia, $\mathrm{P}_{2} \mathrm{Y}_{12}$ inhibitors should be restarted within 48 hours after surgery. ${ }^{[149-151]}$

2. It may be considered to restart $\mathrm{P}_{2} \mathrm{Y}_{12}$ inhibitors within 3 to 4 days postoperatively, when the risk for ischemia is not high (e.g. recent stent implantation $>1$ month or ACS without stenting). ${ }^{[12,26,147,152-157]}$

\section{Anticoagulant Therapy}

\section{Mechanical valve}

1. Anticoagulant treatment with UFH and VKA should be started on the first postoperative day and maintained, until the INR is in therapeutic range. ${ }^{[158,159]}$

2. In case of bleeding risk, VKA may be restarted, whenever it is deemed safe, preferably within 48 hours.

3. In patients with an indication for postoperative therapeutic bridging, it is reasonable to start UFH 12 to 24 hours after surgery.

4. Low-molecular-weight heparin may be considered as an alternative bridging strategy to UFH 24 to 48 hours after surgery. ${ }^{[39,160]}$

5. It is reasonable to restart VKA on the first postoperative day, and lifelong oral anticoagulation with VKA is recommended for all patients. ${ }^{[2,158]}$

6. DOACs are not recommended in patients with a mechanical valve prosthesis. ${ }^{[161]}$

7. The addition of low-dose ASA (75 to $100 \mathrm{mg} /$ day) to VKA should be considered in case of concomitant atherosclerotic disease or thromboembolism, despite an adequate INR. ${ }^{[161-165]}$

\section{Bioprosthetic valve}

1. VKA is reasonable on a lifelong basis for patients with a surgical or transcatheter bioprothesis who have other indications for anticoagulation. 
2. VKA may be considered for the first 3 months after surgical implantation of an aortic bioprosthesis. ${ }^{[166]}$

\section{Others}

1. VKA should be considered for the first 3 months after mitral or tricuspid valve repair or valvesparing procedures.

2. DAPT may be considered after TAVI, if any of anticoagulants are not indicated. ${ }^{[167]}$

\section{BLOOD MANAGEMENT IN PEDIATRIC CARDIAC SURGERY}

In congenital cardiac surgery, the indications and complications of transfusion show a considerable differences than in adults. These differences are predominantly related to the physiological and developmental factors, as well as pathophysiology of the diseases encountered in the pediatric population. Although developing an evidence-based algorithm is challenging, the basic principle of transfusion is always the same: transfusion of the right blood product to the right patient at the right time, and the right indication.

Unfortunately, many of the parameters in an infant/child undergoing cardiac surgery are not unique. More importantly, it is not possible to evaluate the algorithms of blood conservation on evidence-based implementations. Therefore, possible scenarios for low- and high-risk patients may be defined and flowcharts for blood conservation may be recommended. ${ }^{[168]}$

\section{Preoperative Recommendations}

1. Anemia, iron deficiency, and history of bleeding or coagulation disorders should be evaluated preoperatively.

2. A multidisciplinary approach for the diagnosis and treatment of preoperative anemia should be standardized.

3. The discontinuation of antithrombotic treatment should be optimized.

4. Autologous blood donation may be considered in selected cases. ${ }^{[17,169-172]}$

\section{Intraoperative Recommendations}

5. Meticulous surgical technique for minimizing blood loss should be provided. Cyanotic patients, those undergoing a reoperation, and newborns are at a higher risk for bleeding.

6. Factors related to $\mathrm{CPB}$ :
- Hemodilution-optimal Hct level: Although there is no consensus about an optimal Hct level in pediatric cardiac surgery, $25 \%$ may be considered. ${ }^{[173]}$

- Techniques for hemoconcentration: Conventional or MUF may be used in reversing the effects of hemodilution. ${ }^{[174]}$ Optimal management of the composition of prime solution is recommended.

- Optimal management of hypothermia during CPB is reasonable.

- Cell-savers may be used in selected pediatric cases. ${ }^{[175]}$

- Optimal algorithm for anticoagulation and neutralization during CPB should be provided.

- Antifibrinolytics may be useful to avoid bleeding in pediatric population. ${ }^{[176]}$

- To analyze coagulation system, VET can be used, particularly in case of bleeding. ${ }^{[177]}$

- Recombinant coagulation factors may be administered in case of bleeding. ${ }^{[178]}$

\section{ULTRA-BRIEF STEPS OF PBM}

1. Identify the risk for thrombosis and bleeding.

2. Treat anemia.

3. Optimize cessation and bridging of antithrombotic drugs.

4. Use antifibrinolytics.

5. Optimize anticoagulation during CPB.

6. Optimize volume therapy.

7. Minimize hemodilution.

8. Diagnose and treat bleeding promptly.

9. Use an individualized and VET-guided approach for the use of blood products.

10. Choose the optimal timing to restart antithrombotic drugs.

In conclusion, patient blood management should be a philosophy for the Heart Team to improve the outcomes of surgical procedures and postoperative process. Each center should establish its own algorithm and train the whole team for a complete application. This is the first report in Turkey regarding this issue and will be updated and improved every two years. As a continuation of this report, a web-based, multi-center prospective study is planned to be initiated by the Turkish Society of Cardiovascular Surgery and Society of Cardio-Vascular-Thoracic Anaesthesia and Intensive Care. The analysis of this study would provide a great source of scientific data which would guide future applications and update current knowledge. 


\section{Patient Blood Management Study Group Members}

Aylin Yıldırır, Ahmet Hakan Vural, Aslı Demir, Ertekin Utku Ünal, Hüseyin İlksen Toprak, Nevzat Erdil, Yeşim Aydınok, Şahin Bozok, Ersin Kadiroğulları, Yüksel Atay, Tülün Öztürk, Osman Nuri Tuncer, Şahin Şenay, Serdar Akansel, Murat Acarel, Uğur Kısa, Suna Gören, Tuğra Gençpınar, Ozan Onur Balkanay, Seden Kocabaş, Barış Durukan, Serdar Günaydın, Atike Tekeli Kunt, Muharrem Koçyiğit, Levent Mavioğlu, Ümit Karadeniz, Cem Alhan, Alper Kararmaz, Nihan Yapıcı, Elif Başağan Moğol, İsmail Yürekli, Büşra Yetkin Tezcan, Evren Özçınar, Mehmet Ali Astarcığlu, Arda Özyüksel, Filiz İzgi Coşkun.

\section{Declaration of conflicting interests}

The authors declared no conflicts of interest with respect to the authorship and/or publication of this article.

\section{Funding}

The authors received no financial support for the research and/or authorship of this article.

\section{REFERENCES}

1. Ranucci M, Baryshnikova E, Castelvecchio S, Pelissero G; Surgical and Clinical Outcome Research (SCORE) Group. Major bleeding, transfusions, and anemia: the deadly triad of cardiac surgery. Ann Thorac Surg 2013;96:478-85.

2. Pagano D, Milojevic M, Meesters MI, Benedetto U, Bolliger D, von Heymann C, et al. 2017 EACTS/EACTA Guidelines on patient blood management for adult cardiac surgery. Eur J Cardiothorac Surg 2018;53:79-111.

3. Kudsioğlu T, Ertugay S, editors. Hasta Kan Yönetiminde Ortak Görüş. Ankara: Sözkesen Matbaacılık; 2019.

4. Sahu S, Hemlata1, Verma A. Adverse events related to blood transfusion. Indian J Anaesth 2014;58:543-51.

5. Wilkerson DK, Rosen AL, Gould SA, Sehgal LR, Sehgal HL, Moss GS. Oxygen extraction ratio: a valid indicator of myocardial metabolism in anemia. J Surg Res 1987;42:629-34.

6. Alghamdi AA, Davis A, Brister S, Corey P, Logan A. Development and validation of Transfusion Risk Understanding Scoring Tool (TRUST) to stratify cardiac surgery patients according to their blood transfusion needs. Transfusion 2006;46:1120-9.

7. Klein AA, Collier T, Yeates J, Miles LF, Fletcher SN, Evans $\mathrm{C}$, et al. The ACTA PORT-score for predicting perioperative risk of blood transfusion for adult cardiac surgery. Br J Anaesth 2017;119:394-401.

8. Ranucci M, Castelvecchio S, Frigiola A, Scolletta S, Giomarelli P, Biagioli B. Predicting transfusions in cardiac surgery: the easier, the better: the Transfusion Risk and Clinical Knowledge score. Vox Sang 2009;96:324-32.

9. Vuylsteke A, Pagel C, Gerrard C, Reddy B, Nashef S, Aldam $\mathrm{P}$, et al. The Papworth Bleeding Risk Score: a stratification scheme for identifying cardiac surgery patients at risk of excessive early postoperative bleeding. Eur J Cardiothorac Surg 2011;39:924-30.

10. Kristensen KL, Rauer LJ, Mortensen PE, Kjeldsen BJ. Reoperation for bleeding in cardiac surgery. Interact Cardiovasc Thorac Surg 2012;14:709-13.
11. Ranucci M, Bozzetti G, Ditta A, Cotza M, Carboni G, Ballotta A. Surgical reexploration after cardiac operations: why a worse outcome? Ann Thorac Surg 2008;86:1557-62.

12. Ferraris VA, Saha SP, Oestreich JH, Song HK, Rosengart T, Reece TB, et al. 2012 update to the Society of Thoracic Surgeons guideline on use of antiplatelet drugs in patients having cardiac and noncardiac operations. Ann Thorac Surg 2012;94:1761-81.

13. Dai L, Mick SL, McCrae KR, Houghtaling PL, Sabik JF 3rd, Blackstone EH, et al. Preoperative anemia in cardiac operation: does hemoglobin tell the whole story? Ann Thorac Surg 2018;105:100-7.

14. Hogan M, Klein AA, Richards T. The impact of anaemia and intravenous iron replacement therapy on outcomes in cardiac surgery. Eur J Cardiothorac Surg 2015;47:218-26.

15. Musallam KM, Tamim HM, Richards T, Spahn DR, Rosendaal FR, Habbal A, et al. Preoperative anaemia and postoperative outcomes in non-cardiac surgery: a retrospective cohort study. Lancet 2011;378:1396-407.

16. Fowler AJ, Ahmad T, Phull MK, Allard S, Gillies MA, Pearse RM. Meta-analysis of the association between preoperative anaemia and mortality after surgery. Br J Surg 2015;102:1314-24.

17. Klein AA, Collier TJ, Brar MS, Evans C, Hallward G, Fletcher SN, et al. The incidence and importance of anaemia in patients undergoing cardiac surgery in the UK - the first Association of Cardiothoracic Anaesthetists national audit. Anaesthesia 2016;71:627-35.

18. Muñoz M, Acheson AG, Auerbach M, Besser M, Habler O, Kehlet $\mathrm{H}$, et al. International consensus statement on the peri-operative management of anaemia and iron deficiency. Anaesthesia 2017;72:233-47.

19. Muñoz M, Gómez-Ramírez S, Kozek-Langeneker S, Shander A, Richards T, Pavía J, et al. 'Fit to fly': overcoming barriers to preoperative haemoglobin optimization in surgical patients. Br J Anaesth 2015;115:15-24.

20. Taner Ş, Ertugay S. Preoperatif antitrombotik tedavilerin düzenlenmesi. In: Ertugay S, editor. Hasta Kan Yönetiminde Ortak Görüş: Ankara: Sözkesen Matbaacılık; 2019. s. 15-41.

21. Gwon HC, Hahn JY, Park KW, Song YB, Chae IH, Lim DS, et al. Six-month versus 12-month dual antiplatelet therapy after implantation of drug-eluting stents: the Efficacy of Xience/Promus Versus Cypher to Reduce Late Loss After Stenting (EXCELLENT) randomized, multicenter study. Circulation 2012;125:505-13.

22. Heestermans AA, van Werkum JW, Zwart B, van der Heyden JA, Kelder JC, Breet NJ, et al. Acute and subacute stent thrombosis after primary percutaneous coronary intervention for ST-segment elevation myocardial infarction: incidence, predictors and clinical outcome. J Thromb Haemost 2010;8:2385-93.

23. Spertus JA, Kettelkamp R, Vance C, Decker C, Jones PG, Rumsfeld JS, et al. Prevalence, predictors, and outcomes of premature discontinuation of thienopyridine therapy after drug-eluting stent placement: results from the PREMIER registry. Circulation. 2006;113:2803-9.

24. van Werkum JW, Heestermans AA, Zomer AC, Kelder JC, Suttorp MJ, Rensing BJ, et al. Predictors of coronary stent 
thrombosis: the Dutch Stent Thrombosis Registry. J Am Coll Cardiol 2009;53:1399-409.

25. Banerjee S, Angiolillo DJ, Boden WE, Murphy JG, Khalili $\mathrm{H}$, Hasan AA, et al. Use of Antiplatelet Therapy/DAPT for Post-PCI Patients Undergoing Noncardiac Surgery. J Am Coll Cardiol 2017;69:1861-70.

26. Sousa-Uva M, Head SJ, Milojevic M, Collet JP, Landoni G, Castella M, et al. 2017 EACTS Guidelines on perioperative medication in adult cardiac surgery. Eur J Cardiothorac Surg 2018;53:5-33.

27. Sousa-Uva M, Storey R, Huber K, Falk V, Leite-Moreira AF, Amour J, et al. Expert position paper on the management of antiplatelet therapy in patients undergoing coronary artery bypass graft surgery. Eur Heart J 2014;35:1510-4.

28. Rossini R, Musumeci G, Visconti LO, Bramucci E, Castiglioni B, De Servi S, et al. Perioperative management of antiplatelet therapy in patients with coronary stents undergoing cardiac and non-cardiac surgery: a consensus document from Italian cardiological, surgical and anaesthesiological societies. EuroIntervention 2014;10:38-46.

29. Vivas D, Roldán I, Ferrandis R, Marín F, Roldán V, Tello-Montoliu A, et al. Perioperative and Periprocedural Management of Antithrombotic Therapy: Consensus Document of SEC, SEDAR, SEACV, SECTCV, AEC, SECPRE, SEPD, SEGO, SEHH, SETH, SEMERGEN, SEMFYC, SEMG, SEMICYUC, SEMI, SEMES, SEPAR, SENEC, SEO, SEPA, SERVEI, SECOT and AEU. Rev Esp Cardiol (Engl Ed) 2018;71:553-64.

30. Della Corte A, Bancone C, Spadafora A, Borrelli M, Galdieri N, Quintiliano SN, et al. Postoperative bleeding in coronary artery bypass patients on double antiplatelet therapy: predictive value of preoperative aggregometry. Eur J Cardiothorac Surg 2017;52:901-8.

31. Leunissen TC, Janssen PW, Ten Berg JM, Moll FL, Korporaal SJ, de Borst GJ, et al. The use of platelet reactivity testing in patients on antiplatelet therapy for prediction of bleeding events after cardiac surgery. Vascul Pharmacol 2016;77:19-27.

32. Petricevic M, Kopjar T, Biocina B, Milicic D, Kolic K, Boban $\mathrm{M}$, et al. The predictive value of platelet function point-ofcare tests for postoperative blood loss and transfusion in routine cardiac surgery: a systematic review. Thorac Cardiovasc Surg 2015;63:2-20.

33. Douketis JD, Spyropoulos AC, Spencer FA, Mayr M, Jaffer AK, Eckman MH, et al. Perioperative management of antithrombotic therapy: Antithrombotic Therapy and Prevention of Thrombosis, 9th ed: American College of Chest Physicians Evidence-Based Clinical Practice Guidelines. Chest 2012;141(2 Suppl):e326S-e50S.

34. Nishimura RA, Otto CM, Bonow RO, Carabello BA, Erwin JP 3rd, Guyton RA, et al. 2014 AHA/ACC guideline for the management of patients with valvular heart disease: executive summary: a report of the American College of Cardiology/American Heart Association Task Force on Practice Guidelines. J Am Coll Cardiol 2014;63:2438-88.

35. O'Donnell MJ, Kearon C, Johnson J, Robinson M, Zondag M, Turpie I, et al. Brief communication: Preoperative anticoagulant activity after bridging low-molecular-weight heparin for temporary interruption of warfarin. Ann Intern Med 2007;146:184-7.

36. Ageno W, Gallus AS, Wittkowsky A, Crowther M, Hylek EM, Palareti G. Oral anticoagulant therapy: Antithrombotic Therapy and Prevention of Thrombosis, 9th ed: American College of Chest Physicians Evidence-Based Clinical Practice Guidelines. Chest 2012;141(2 Suppl):e44S-e88S.

37. Chai-Adisaksopha C, Hillis C, Siegal DM, Movilla R, Heddle N, Iorio A, et al. Prothrombin complex concentrates versus fresh frozen plasma for warfarin reversal. A systematic review and meta-analysis. Thromb Haemost 2016;116:879-90.

38. Dhakal P, Rayamajhi S, Verma V, Gundabolu K, Bhatt VR. Reversal of anticoagulation and management of bleeding in patients on anticoagulants. Clin Appl Thromb Hemost 2017;23:410-5.

39. Heidbuchel H, Verhamme P, Alings M, Antz M, Diener HC, Hacke W, et al. Updated European Heart Rhythm Association Practical Guide on the use of non-vitamin K antagonist anticoagulants in patients with non-valvular atrial fibrillation. Europace 2015;17:1467-507.

40. Glund S, Stangier J, van Ryn J, Schmohl M, Moschetti $\mathrm{V}$, Haazen $\mathrm{W}$, et al. Effect of age and renal function on idarucizumab pharmacokinetics and idarucizumabmediated reversal of dabigatran anticoagulant activity in a randomized, double-blind, crossover phase Ib study. Clin Pharmacokinet 2017;56:41-54.

41. Shaw JR, Siegal DM. Pharmacological reversal of the direct oral anticoagulants-A comprehensive review of the literature. Res Pract Thromb Haemost 2018;2:251-65.

42. Connolly SJ, Crowther M, Eikelboom JW, Gibson CM, Curnutte JT, Lawrence JH, et al. Full study report of andexanet alfa for bleeding associated with factor xa inhibitors. N Engl J Med 2019;380:1326-35.

43. Ellington TM. A systematic and evidence-based review of published and pending reports of andexanet alfa. J Pharm Pract 2019:897190018822556.

44. Kozek-Langenecker SA. Perioperative coagulation monitoring. Best Pract Res Clin Anaesthesiol 2010;24:2740.

45. van Veen JJ, Spahn DR, Makris M. Routine preoperative coagulation tests: an outdated practice? $\mathrm{Br} \mathrm{J}$ Anaesth 2011;106:1-3

46. Rock G, Berger R, Bormanis J, Giulivi A, ElSaadany $\mathrm{S}$, Afzal $\mathrm{M}$, et al. A review of nearly two decades in an autologous blood programme: The rise and fall of activity. Transfus Med 2006;16:307-11.

47. Savoia HF, Metz J, Maxwell EL, Hauesler MN, Mellor J, Kiely S. Utilization of preoperative autologous blood donation in elective surgery. ANZ J Surg 2002;72:557-60.

48. Yazer MH, Waters JH. How do I implement a hospital-based blood management program? Transfusion 2012;52:1640-5.

49. Ben Amor I, Rekik T, Louati N, Lahiani W, Rekik H, Peyrard T, et al. Difficulties of the care of public antigen alloimmunization. Transfus Clin Biol 2016;23:103-5.

50. Priye S, Sathyanarayan J, Shivaprakash S, Reddy D. Perioperative management of patient with Bombay blood 
group undergoing mitral valve replacement. Indian J Anaesth 2015;59:811-3.

51. Gaudino M, Angelini GD, Antoniades C, Bakaeen F, Benedetto U, Calafiore AM, et al. Off-pump coronary artery bypass grafting: 30 years of debate. J Am Heart Assoc 2018;7:e009934.

52. Puskas JD, Martin J, Cheng DC, Benussi S, Bonatti JO, Diegeler A, et al. ISMICS consensus conference and statements of randomized controlled trials of off-pump versus conventional coronary artery bypass surgery. Innovations (Phila) 2015;10:219-29.

53. Bakir I, Casselman FP, Wellens F, Jeanmart H, De Geest R, Degrieck I, Minimally invasive versus standard approach aortic valve replacement: a study in 506 patients. Ann Thorac Surg 2006;81:1599-604.

54. Falk V, Cheng DC, Martin J, Diegeler A, Folliguet TA, Nifong LW, et al. Minimally invasive versus open mitral valve surgery: a consensus statement of the international society of minimally invasive coronary surgery (ISMICS) 2010. Innovations (Phila) 2011;6:66-76.

55. Sündermann SH, Sromicki J, Rodriguez Cetina Biefer H, Seifert B, Holubec T, Falk V, et al. Mitral valve surgery: right lateral minithoracotomy or sternotomy? A systematic review and meta-analysis. J Thorac Cardiovasc Surg 2014;148:1989-95.e4.

56. Cap AP, Beckett A, Benov A, Borgman M, Chen J, Corley JB, et al. Whole blood transfusion. Mil Med 2018(suppl_2);183:44-51.

57. Jobes D, Wolfe Y, O'Neill D, Calder J, Jones L, SesokPizzini D, et al. Toward a definition of "fresh" whole blood: an in vitro characterization of coagulation properties in refrigerated whole blood for transfusion. Transfusion 2011;51:43-51.

58. Manno CS, Hedberg KW, Kim HC, Bunin GR, Nicolson S, Jobes D, et al. Comparison of the hemostatic effects of fresh whole blood, stored whole blood, and components after open heart surgery in children. Blood 1991;77:930-6.

59. Valleley MS, Buckley KW, Hayes KM, Fortuna RR, Geiss DM, Holt DW. Are there benefits to a fresh whole blood vs. packed red blood cell cardiopulmonary bypass prime on outcomes in neonatal and pediatric cardiac surgery? J Extra Corpor Technol 2007;39:168-76.

60. Henry DA, Carless PA, Moxey AJ, O'Connell D, Stokes BJ, Fergusson DA, et al. Anti-fibrinolytic use for minimising perioperative allogeneic blood transfusion. Cochrane Database Syst Rev 2011;3:CD001886.

61. Ker K, Edwards P, Perel P, Shakur H, Roberts I. Effect of tranexamic acid on surgical bleeding: systematic review and cumulative meta-analysis. BMJ 2012;344:e3054.

62. Myles PS, Smith JA, Forbes A, Silbert B, Jayarajah M, Painter $\mathrm{T}$, et al. Tranexamic acid in patients undergoing coronary-artery surgery. N Engl J Med 2017;376:136-48.

63. Brown JR, Birkmeyer NJ, O'Connor GT. Meta-analysis comparing the effectiveness and adverse outcomes of antifibrinolytic agents in cardiac surgery. Circulation 2007;115:2801-13.

64. Sedrakyan A, Treasure T, Elefteriades JA. Effect of aprotinin on clinical outcomes in coronary artery bypass graft surgery: a systematic review and meta-analysis of randomized clinical trials. J Thorac Cardiovasc Surg 2004;128:442-8.

65. Howle RC. Is Acute Normovolemic Hemodilution Useful in Modern Cardiac Anesthesia? Anesth Analg 2017;124:1013.

66. Barile L, Fominskiy E, Di Tomasso N, Alpìzar Castro LE, Landoni G, De Luca M, et al. Acute normovolemic hemodilution reduces allogeneic red blood cell transfusion in cardiac surgery: a systematic review and meta-analysis of randomized trials. Anesth Analg 2017;124:743-52.

67. Stehling L, Zauder HL. Acute normovolemic hemodilution. Transfusion 1991;31:857-68.

68. Martin E, Hansen E, Peter K. Acute limited normovolemic hemodilution: a method for avoiding homologous transfusion. World J Surg 1987;11:53-9.

69. Finley A, Greenberg C. Review article: heparin sensitivity and resistance: management during cardiopulmonary bypass. Anesth Analg 2013;116:1210-22.

70. Shore-Lesserson L, Baker RA, Ferraris V, Greilich PE, Fitzgerald D, Roman P, et al. STS/SCA/AmSECT clinical practice guidelines: Anticoagulation during cardiopulmonary bypass. J Extra Corpor Technol 2018;50:5-18.

71. Koster A, Fischer T, Praus M, Haberzettl H, Kuebler WM, Hetzer R, et al. Hemostatic activation and inflammatory response during cardiopulmonary bypass: impact of heparin management. Anesthesiology 2002;97:837-41.

72. Task Force on Patient Blood Management for Adult Cardiac Surgery of the European Association for CardioThoracic Surgery (EACTS) and the European Association of Cardiothoracic Anaesthesiology (EACTA), Boer C, Meesters MI, Milojevic M, Benedetto U, Bolliger D, et al. 2017 EACTS/EACTA Guidelines on patient blood management for adult cardiac surgery. J Cardiothorac Vasc Anesth 2018;32:88-120.

73. Teoh KH, Young E, Blackall MH, Roberts RS, Hirsh J. Can extra protamine eliminate heparin rebound following cardiopulmonary bypass surgery? J Thorac Cardiovasc Surg 2004;128:211-9.

74. Boer C, Meesters MI, Veerhoek D, Vonk ABA. Anticoagulant and side-effects of protamine in cardiac surgery: a narrative review. Br J Anaesth 2018;120:914-27.

75. Selleng S, Selleng K, Wollert HG, Muellejans B, Lietz T, Warkentin TE, et al. Heparin-induced thrombocytopenia in patients requiring prolonged intensive care unit treatment after cardiopulmonary bypass. J Thromb Haemost 2008;6:428-35.

76. Thielmann M, Bunschkowski M, Tossios P, Selleng S, Marggraf G, Greinacher A, et al. Perioperative thrombocytopenia in cardiac surgical patients - incidence of heparin-induced thrombocytopenia, morbidities and mortality. Eur J Cardiothorac Surg 2010;37:1391-5.

77. Crowther MA, Cook DJ, Albert M, Williamson D, Meade M, Granton J, et al. The 4Ts scoring system for heparininduced thrombocytopenia in medical-surgical intensive care unit patients. J Crit Care 2010;25:287-93.

78. Lubenow N, Eichler P, Lietz T, Farner B, Greinacher A. Lepirudin for prophylaxis of thrombosis in patients with acute isolated heparin-induced thrombocytopenia: 
an analysis of 3 prospective studies. Blood 2004;104:3072-7.

79. Wallis DE, Workman DL, Lewis BE, Steen L, Pifarre R, Moran JF. Failure of early heparin cessation as treatment for heparin-induced thrombocytopenia. Am J Med 1999;106:629-35.

80. Warkentin TE, Kelton JG. A 14-year study of heparininduced thrombocytopenia. Am J Med 1996;101:502-7.

81. Russell JA, Navickis RJ, Wilkes MM. Albumin versus crystalloid for pump priming in cardiac surgery: metaanalysis of controlled trials. J Cardiothorac Vasc Anesth 2004;18:429-37.

82. Bhaskaran K, Arumugam G, Vinay Kumar PV. A prospective, randomized, comparison study on effect of perioperative use of chloride liberal intravenous fluids versus chloride restricted intravenous fluids on postoperative acute kidney injury in patients undergoing off-pump coronary artery bypass grafting surgeries. Ann Card Anaesth 2018;21:413-8.

83. Hahn RG, Lyons G. The half-life of infusion fluids: An educational review. Eur J Anaesthesiol 2016;33:475-82.

84. Protsyk V, Rasmussen BS, Guarracino F, Erb J, Turton E, Ender J. Fluid management in cardiac surgery: results of a survey in european cardiac anesthesia departments. J Cardiothorac Vasc Anesth 2017;31:1624-9.

85. Jacob M, Fellahi JL, Chappell D, Kurz A. The impact of hydroxyethyl starches in cardiac surgery: a meta-analysis. Crit Care 2014;18:656.

86. Qureshi SH, Rizvi SI, Patel NN, Murphy GJ. Meta-analysis of colloids versus crystalloids in critically ill, trauma and surgical patients. Br J Surg 2016;103:14-26.

87. Rasmussen KC, Secher NH, Pedersen T. Effect of perioperative crystalloid or colloid fluid therapy on hemorrhage, coagulation competence, and outcome: A systematic review and stratified meta-analysis. Medicine (Baltimore) 2016;95:e4498.

88. Durukan AB, Gürbüz HA, Durukan E, Salman N, Tavlaşoğlu M, Serter FT, et al. An evaluation of $6 \%$ hydroxyethyl starch $130 / 0.4$ use in fluid therapy following coronary artery surgery. Turk Gogus Kalp Dama 2013;21:276-83.

89. Perel P, Roberts I, Ker K. Colloids versus crystalloids for fluid resuscitation in critically ill patients. Cochrane Database Syst Rev 2013;2:CD000567.

90. Schramko A, Suojaranta-Ylinen R, Niemi T, Pesonen E, Kuitunen A, Raivio P, et al. The use of balanced HES 130/0.42 during complex cardiac surgery; effect on blood coagulation and fluid balance: a randomized controlled trial. Perfusion 2015;30:224-32.

91. Ryhammer PK, Tang M, Hoffmann-Petersen J, Leonaviciute D, Greisen J, Storebjerg Gissel M, et al. Colloids in cardiac surgery-friend or foe? J Cardiothorac Vasc Anesth 2017;31:1639-48.

92. Shaw A, Raghunathan K. Fluid management in cardiac surgery: colloid or crystalloid? Anesthesiol Clin 2013;31:269-80.

93. Momeni M, Nkoy Ena L, Van Dyck M, Matta A, Kahn D, Thiry D, et al. The dose of hydroxyethyl starch $6 \%$ 130/0.4 for fluid therapy and the incidence of acute kidney injury after cardiac surgery: A retrospective matched study. PLoS One 2017;12:e0186403.
94. BesserMW, Klein AA. The coagulopathy of cardiopulmonary bypass. Crit Rev Clin Lab Sci 2010;47:197-212.

95. Despotis GJ, Avidan MS, Hogue CW Jr. Mechanisms and attenuation of hemostatic activation during extracorporeal circulation. Ann Thorac Surg 2001;72:S1821-31.

96. Mart Bakır Ö, Özer Z, Eskandari G, Sucu N. Kalp cerrahisinde kan transfüzyonu için belirleyici olabilecek preoperatif değişkenler. Gögüs Kalp Damar Anestezi ve Yoğun Bakım Derneği Dergisi 2012;3:57-62.

97. Anastasiadis K, Murkin J, Antonitsis P, Bauer A, Ranucci M, Gygax E, et al. Use of minimal invasive extracorporeal circulation in cardiac surgery: principles, definitions and potential benefits. A position paper from the Minimal invasive Extra-Corporeal Technologies international Society (MiECTiS). Interact Cardiovasc Thorac Surg 2016;22:647-62.

98. Anastasiadis K, Antonitsis P, Haidich AB, Argiriadou $\mathrm{H}$, Deliopoulos A, Papakonstantinou C. Use of minimal extracorporeal circulation improves outcome after heart surgery; a systematic review and meta-analysis of randomized controlled trials. Int J Cardiol 2013;164:158-69.

99. Gunaydin S, Sari T, McCusker K, Schonrock U, Zorlutuna Y. Clinical evaluation of minimized extracorporeal circulation in high-risk coronary revascularization: impact on air handling, inflammation, hemodilution and myocardial function. Perfusion 2009;24:153-62.

100. Harling L, Warren OJ, Martin A, Kemp PR, Evans PC, Darzi A, et al. Do miniaturized extracorporeal circuits confer significant clinical benefit without compromising safety? A meta-analysis of randomized controlled trials. ASAIO J 2011;57:141-51.

101. Sun P, Ji B, Sun Y, Zhu X, Liu J, Long C, et al. Effects of retrograde autologous priming on blood transfusion and clinical outcomes in adults: a meta-analysis. Perfusion 2013;28:238-43.

102. Saczkowski R, Bernier PL, Tchervenkov CI, Arellano R. Retrograde autologous priming and allogeneic blood transfusions: a meta-analysis. Interact Cardiovasc Thorac Surg 2009;8:373-6.

103. Blaudszun G, Butchart A, Klein AA. Blood conservation in cardiac surgery. Transfus Med 2018;28:168-80.

104. Damgaard S, Nielsen CH, Andersen LW, Bendtzen K, Tvede M, Steinbrüchel DA. Cell saver for on-pump coronary operations reduces systemic inflammatory markers: a randomized trial. Ann Thorac Surg 2010;89:1511-7.

105. Gäbel J, Westerberg M, Bengtsson A, Jeppsson A. Cell salvage of cardiotomy suction blood improves the balance between pro- and anti-inflammatory cytokines after cardiac surgery. Eur J Cardiothorac Surg 2013;44:506-11.

106. Olmos Rodríguez M, Ballester Hernández JA, Arteta Bárcenas MT, Rodríguez Cerezo A, Vidarte Ortiz de Artiñano MA, Veiga Alameda C. Effect of priming solution and ultrafiltration on post-operative bleeding and blood transfusion in cardiac surgery. Randomized controlled trial. Rev Esp Anestesiol Reanim 2015;62:81-9.

107. Torina AG, Silveira-Filho LM, Vilarinho KA, Eghtesady P, Oliveira PP, Sposito AC, et al. Use of modified ultrafiltration in adults undergoing coronary artery bypass grafting is 
associated with inflammatory modulation and less postoperative blood loss: a randomized and controlled study. J Thorac Cardiovasc Surg 2012;144:663-70.

108. Boodhwani M, Williams K, Babaev A, Gill G, Saleem N, Rubens FD. Ultrafiltration reduces blood transfusions following cardiac surgery: A meta-analysis. Eur J Cardiothorac Surg 2006;30:892-7.

109. Mongero LB, Tesdahl EA, Stammers A, Weinstein S. The influence of ultrafiltration on red blood cell transfusion during cardiopulmonary bypass. Perfusion 2019;34:303-9.

110. Casbard AC, Williamson LM, Murphy MF, Rege K, Johnson $\mathrm{T}$. The role of prophylactic fresh frozen plasma in decreasing blood loss and correcting coagulopathy in cardiac surgery. A systematic review. Anaesthesia 2004;59:550-8.

111. Yang L, Stanworth S, Hopewell S, Doree C, Murphy M. Is fresh-frozen plasma clinically effective? An update of a systematic review of randomized controlled trials. Transfusion 2012;52:1673-86.

112. Gödje O, Gallmeier U, Schelian M, Grünewald M, Mair H. Coagulation factor XIII reduces postoperative bleeding after coronary surgery with extracorporeal circulation. Thorac Cardiovasc Surg 2006;54:26-33.

113. Bolliger D, Görlinger K, Tanaka KA. Pathophysiology and treatment of coagulopathy in massive hemorrhage and hemodilution. Anesthesiology 2010;113:1205-19.

114. Bilecen S, de Groot JA, Kalkman CJ, Spanjersberg AJ, Brandon Bravo Bruinsma GJ, Moons KG, et al. Effect of Fibrinogen Concentrate on Intraoperative Blood Loss Among Patients With Intraoperative Bleeding During HighRisk Cardiac Surgery: A Randomized Clinical Trial. JAMA 2017;317:738-47.

115. Karkouti K, Callum J, Crowther MA, McCluskey SA, Pendergrast J, Tait G, et al. The relationship between fibrinogen levels after cardiopulmonary bypass and large volume red cell transfusion in cardiac surgery: an observational study. Anesth Analg 2013;117:14-22.

116. Demeyere R, Gillardin S, Arnout J, Strengers PF. Comparison of fresh frozen plasma and prothrombin complex concentrate for the reversal of oral anticoagulants in patients undergoing cardiopulmonary bypass surgery: a randomized study. Vox Sang 2010;99:251-60.

117. Levi M, Cromheecke ME, de Jonge E, Prins MH, de Mol BJ, Briët E, et al. Pharmacological strategies to decrease excessive blood loss in cardiac surgery: a meta-analysis of clinically relevant endpoints. Lancet 1999;354:1940-7.

118. Wademan BH, Galvin SD. Desmopressin for reducing postoperative blood loss and transfusion requirements following cardiac surgery in adults. Interact Cardiovasc Thorac Surg 2014;18:360-70.

119. Gill R, Herbertson M, Vuylsteke A, Olsen PS, von Heymann C, Mythen M, et al. Safety and efficacy of recombinant activated factor VII: a randomized placebo-controlled trial in the setting of bleeding after cardiac surgery. Circulation 2009;120:21-7.

120. Simpson E, Lin Y, Stanworth S, Birchall J, Doree C, Hyde C. Recombinant factor VIIa for the prevention and treatment of bleeding in patients without haemophilia. Cochrane Database Syst Rev 2012;3:CD005011.
121. Singh SP, Chauhan S, Choudhury M, Malik V, Choudhary SK. Recombinant activated factor VII in cardiac surgery: single-center experience. Asian Cardiovasc Thorac Ann 2014;22:148-54.

122. Samudrala S1. Topical hemostatic agents in surgery: a surgeon's perspective. AORN J 2008;88:S2-11.

123. Spotnitz WD, Burks S. State-of-the-art review: Hemostats, sealants, and adhesives II: Update as well as how and when to use the components of the surgical toolbox. Clin Appl Thromb Hemost 2010;16:497-514.

124. Abrishami A, Chung F, Wong J. Topical application of antifibrinolytic drugs for on-pump cardiac surgery: a systematic review and meta-analysis. Can J Anaesth 2009;56:202-12.

125. Spotnitz WD. Hemostats, sealants, and adhesives: a practical guide for the surgeon. Am Surg 2012;78:1305-21.

126. Ker K, Beecher D, Roberts I. Topical application of tranexamic acid for the reduction of bleeding. Cochrane Database Syst Rev 2013;7:CD010562.

127. Moss CF, Sinha SR. Neurobiology of echolocation in bats. Curr Opin Neurobiol 2003;13:751-8.

128. Dhir A, Tempe DK. Anemia and patient blood management in cardiac surgery-literature review and current evidence. J Cardiothorac Vasc Anesth 2018;32:2726-42.

129. Scolletta S, Simioni P, Campagnolo V, Celiento M, Fontanari $\mathrm{P}$, Guadagnucci A, et al. Patient blood management in cardiac surgery: The "Granducato algorithm". Int J Cardiol 2019;289:37-42.

130. Meesters MI, Koning NJ, Romijn JWA, Loer SA, Boer C. Clinical decision versus thromboelastometry based fresh frozen plasma transfusion in cardiac surgery. Br J Anaesth 2017;118:458-9.

131. Green L, Bolton-Maggs P, Beattie C, Cardigan R, Kallis Y, Stanworth SJ, et al. British Society of Haematology Guidelines on the spectrum of fresh frozen plasma and cryoprecipitate products: their handling and use in various patient groups in the absence of major bleeding. $\mathrm{Br} \mathrm{J}$ Haematol 2018;181:54-67.

132. Pavenski K, Stanworth S, Fung M, Wood EM, Pink J, Murphy MF, et al. Quality of Evidence-Based Guidelines for Transfusion of Red Blood Cells and Plasma: A Systematic Review. Transfus Med Rev 2018 Jun 1. pii: S08877963(18)30017-8.

133. Tayfun G. Kardiyak Cerrahide Transfüzyon Kararı. GKDA Derg 2012;18:27-45.

134. Estcourt LJ, Birchall J, Allard S, Bassey SJ, Hersey P, Kerr JP, et al. Guidelines for the use of platelet transfusions. Br J Haematol 2017;176:365-94.

135. Padhi S, Kemmis-Betty S, Rajesh S, Hill J, Murphy MF; Guideline Development Group. Blood transfusion: summary of NICE guidance. BMJ 2015;351:h5832.

136. Hall TS, Brevetti GR, Skoultchi AJ, Sines JC, Gregory P, Spotnitz AJ. Re-exploration for hemorrhage following open heart surgery differentiation on the causes of bleeding and the impact on patient outcomes. Ann Thorac Cardiovasc Surg 2001;7:352-7.

137. Deppe AC, Weber C, Zimmermann J, Kuhn EW, Slottosch I, Liakopoulos OJ, et al. Point-of-care thromboelastography/ 
thromboelastometry-based coagulation management in cardiac surgery: a meta-analysis of 8332 patients. J Surg Res 2016;203:424-33.

138. Fleming K, Redfern RE, March RL, Bobulski N, Kuehne M, Chen JT, et al. TEG-Directed Transfusion in Complex Cardiac Surgery: Impact on Blood Product Usage. J Extra Corpor Technol 2017;49:283-90.

139. Karkouti K, Callum J, Wijeysundera DN, Rao V, Crowther M, Grocott HP, et al. Point-of-Care Hemostatic Testing in Cardiac Surgery: A Stepped-Wedge Clustered Randomized Controlled Trial. Circulation 2016;134:1152-62.

140. Serraino GF, Murphy GJ. Routine use of viscoelastic blood tests for diagnosis and treatment of coagulopathic bleeding in cardiac surgery: updated systematic review and metaanalysis. Br J Anaesth 2017;118:823-33.

141. Fröjd V, Jeppsson A. Reexploration for bleeding and its association with mortality after cardiac surgery. Ann Thorac Surg 2016;102:109-17.

142. Vivacqua A, Koch CG, Yousuf AM, Nowicki ER, Houghtaling PL, Blackstone EH, et al. Morbidity of bleeding after cardiac surgery: is it blood transfusion, reoperation for bleeding, or both? Ann Thorac Surg 2011;91:1780-90.

143. Grieshaber P, Heim N, Herzberg M, Niemann B, Roth $\mathrm{P}$, Boening A. Active chest tube clearance after cardiac surgery is associated with reduced reexploration rates. Ann Thorac Surg 2018;105:1771-7.

144. Haneya A, Diez C, Kolat P, Suesskind-Schwendi Mv, Ried M, Schmid C, et al. Re-exploration for bleeding or tamponade after cardiac surgery: impact of timing and indication on outcome. Thorac Cardiovasc Surg 2015;63:51-7.

145. Ruel M, Chan V, Boodhwani M, McDonald B, Ni X, Gill $\mathrm{G}$, et al. How detrimental is reexploration for bleeding after cardiac surgery? J Thorac Cardiovasc Surg 2017;154:927-35.

146. Antithrombotic Trialists' Collaboration. Collaborative meta-analysis of randomised trials of antiplatelet therapy for prevention of death, myocardial infarction, and stroke in high risk patients. BMJ 2002;324:71-86.

147. Kolh P, Windecker S, Alfonso F, Collet JP, Cremer J, Falk V, et al. 2014 ESC/EACTS Guidelines on myocardial revascularization: the Task Force on Myocardial Revascularization of the European Society of Cardiology (ESC) and the European Association for Cardio-Thoracic Surgery (EACTS). Developed with the special contribution of the European Association of Percutaneous Cardiovascular Interventions (EAPCI). Eur J Cardiothorac Surg 2014;46:517-92.

148. Musleh G, Dunning J. Does aspirin $6 \mathrm{~h}$ after coronary artery bypass grafting optimise graft patency? Interact Cardiovasc Thorac Surg 2003;2:413-5.

149. Becker RC, Bassand JP, Budaj A, Wojdyla DM, James SK, Cornel JH, et al. Bleeding complications with the P2Y12 receptor antagonists clopidogrel and ticagrelor in the PLATelet inhibition and patient Outcomes (PLATO) trial. Eur Heart J 2011;32:2933-44.

150. Wallentin L, Becker RC, Budaj A, Cannon CP, Emanuelsson $\mathrm{H}$, Held C, et al. Ticagrelor versus clopidogrel in patients with acute coronary syndromes. N Engl J Med 2009;361:1045-57.

151. Wiviott SD, Braunwald E, McCabe CH, Montalescot G,
Ruzyllo W, Gottlieb S, et al. Prasugrel versus clopidogrel in patients with acute coronary syndromes. N Engl J Med 2007;357:2001-15.

152. Deo SV, Dunlay SM, Shah IK, Altarabsheh SE, Erwin PJ, Boilson BA, et al. Dual anti-platelet therapy after coronary artery bypass grafting: is there any benefit? A systematic review and meta-analysis. J Card Surg 2013;28:109-16.

153. Hansson EC, Jidéus L, Åberg B, Bjursten H, Dreifaldt M, Holmgren A, et al. Coronary artery bypass grafting-related bleeding complications in patients treated with ticagrelor or clopidogrel: a nationwide study. Eur Heart J 2016;37:189-97.

154. Held C, Asenblad N, Bassand JP, Becker RC, Cannon CP, Claeys MJ, et al. Ticagrelor versus clopidogrel in patients with acute coronary syndromes undergoing coronary artery bypass surgery: results from the PLATO (Platelet Inhibition and Patient Outcomes) trial. J Am Coll Cardiol 2011;57:672-84.

155. Smith PK, Goodnough LT, Levy JH, Poston RS, Short MA, Weerakkody GJ, et al. Mortality benefit with prasugrel in the TRITON-TIMI 38 coronary artery bypass grafting cohort: risk-adjusted retrospective data analysis. J Am Coll Cardiol 2012;60:388-96.

156. van Diepen S, Fuster V, Verma S, Hamza TH, Siami FS, Goodman SG, et al. Dual Antiplatelet Therapy Versus Aspirin Monotherapy in Diabetics With Multivessel Disease Undergoing CABG: FREEDOM Insights. J Am Coll Cardiol 2017;69:119-27.

157. Verma S, Goodman SG, Mehta SR, Latter DA, Ruel M, Gupta M, et al. Should dual antiplatelet therapy be used in patients following coronary artery bypass surgery? A meta-analysis of randomized controlled trials. BMC Surg 2015;15:112.

158. Patrono C, Coller B, FitzGerald GA, Hirsh J, Roth G. Platelet-active drugs: the relationships among dose, effectiveness, and side effects: the Seventh ACCP Conference on Antithrombotic and Thrombolytic Therapy. Chest 2004;126(3 Suppl):234S-64S.

159. Savonitto S, D'Urbano M, Caracciolo M, Barlocco F, Mariani G, Nichelatti M, et al. Urgent surgery in patients with a recently implanted coronary drug-eluting stent: a phase II study of 'bridging' antiplatelet therapy with tirofiban during temporary withdrawal of clopidogrel. Br J Anaesth 2010;104:285-91.

160. Faraoni D, Levy JH, Albaladejo P, Samama CM; Groupe d'Intérêt en Hémostase Périopératoire. Updates in the perioperative and emergency management of non-vitamin $\mathrm{K}$ antagonist oral anticoagulants. Crit Care 2015;19:203.

161. Eikelboom JW, Connolly SJ, Brueckmann M, Granger CB, Kappetein AP, Mack MJ, et al. Dabigatran versus warfarin in patients with mechanical heart valves. N Engl J Med 2013;369:1206-14.

162. Cannegieter SC, Rosendaal FR, Briët E. Thromboembolic and bleeding complications in patients with mechanical heart valve prostheses. Circulatio 1994;89:635-41.

163. Dentali F, Douketis JD, Lim W, Crowther M. Combined aspirin-oral anticoagulant therapy compared with oral anticoagulant therapy alone among patients at risk for cardiovascular disease: a meta-analysis of randomized trials. Arch Intern Med 2007;167:117-24. 
164. Douketis JD, Spyropoulos AC, Kaatz S, Becker RC, Caprini JA, Dunn AS, et al. Perioperative Bridging Anticoagulation in Patients with Atrial Fibrillation. $N$ Engl J Med 2015;373:823-33.

165. Jones HU, Muhlestein JB, Jones KW, Bair TL, Lavasani F, Sohrevardi M, et al. Preoperative use of enoxaparin compared with unfractionated heparin increases the incidence of re-exploration for postoperative bleeding after open-heart surgery in patients who present with an acute coronary syndrome: clinical investigation and reports. Circulation 2002;106:I19-22.

166. Abdul-Jawad Altisent O, Durand E, Muñoz-García AJ, Nombela-Franco L, Cheema A, Kefer J, et al. Warfarin and antiplatelet therapy versus warfarin alone for treating patients with atrial fibrillation undergoing transcatheter aortic valve replacement. JACC Cardiovasc Interv 2016;9:1706-17

167. Iung B, Rodés-Cabau J. The optimal management of antithrombotic therapy after valve replacement: certainties and uncertainties. Eur Heart J 2014;35:2942-9.

168. Machovec KA, Jooste EH. Pediatric transfusion algorithms: Coming to a cardiac operating room near you. J Cardiothorac Vasc Anesth 2019;33:2017-29.

169. Chakravarthy M. Modifying risks to improve outcome in cardiac surgery: An anesthesiologist's perspective. Ann Card Anaesth 2017;20:226-33.

170. Goobie SM, Faraoni D, Zurakowski D, DiNardo JA. Association of preoperative anemia with postoperative mortality in neonates. JAMA Pediatr 2016;170:855-62.

171. Karkouti K, Wijeysundera DN, Beattie WS; Reducing Bleeding in Cardiac Surgery (RBC) Investigators. Risk associated with preoperative anemia in cardiac surgery: a multicenter cohort study. Circulation 2008;117:478-84.

172. Khan Z, Natarajan G, Sallaam S, Bondarenko I, Walters HL, Delius R, et al. Association between anemia and packed cell transfusion and outcomes of ventricular septal defect and atrioventricular canal repair in children. Pediatr Cardiol 2014;35:471-8.

173. Wypij D, Jonas RA, Bellinger DC, Del Nido PJ, Mayer JE Jr, Bacha EA, et al. The effect of hematocrit during hypothermic cardiopulmonary bypass in infant heart surgery: results from the combined Boston hematocrit trials. J Thorac Cardiovasc Surg 2008;135:355-60.

174. Thompson LD, McElhinney DB, Findlay P, Miller-Hance W, Chen MJ, Minami M, et al. A prospective randomized study comparing volume-standardized modified and conventional ultrafiltration in pediatric cardiac surgery. $\mathbf{J}$ Thorac Cardiovasc Surg 2001;122:220-8.

175. Kwak JG, Park M, Lee J, Lee CH. Multiple approaches to minimize transfusions for pediatric patients in open-heart surgery. Pediatr Cardiol 2016;37:44-9.

176. Koster A, Faraoni D, Levy JH. Antifibrinolytic therapy for cardiac surgery: An update. Anesthesiology 2015;123:214-21.

177. Perez-Ferrer A, Vicente-Sanchez J, Carceles-Baron MD, Van der Linden P, Faraoni D. Early thromboelastometry variables predict maximum clot firmness in children undergoing cardiac and non-cardiac surgery. Br J Anaesth 2015;115:896-902.

178. Galas FR, de Almeida JP, Fukushima JT, Vincent JL, Osawa EA, Zeferino $\mathrm{S}$, et al. Hemostatic effects of fibrinogen concentrate compared with cryoprecipitate in children after cardiac surgery: a randomized pilot trial. J Thorac Cardiovasc Surg 2014;148:1647-55. 